\title{
Yerel Tarih Öğretim Yöntemini Sosyal Bilgiler Dersinde Kullanmak: Yanı Başında Olan Geçmişi Görmek ve Duyumsamak*
}

\section{Using Local History Teaching Method in Social Studies Courses: Seeing and Feeling the Past Next to You}

\author{
Cemile Ayça ÖZTAŞÇı
}

IELEV 125. Yıl Ortaokulu, E-posta: cugur@ielev.k12.tr

orcid.org/ 0000-0002-1039-036X

\section{Yücel KABAPINAR}

Marmara Üniversitesi, Atatürk Eğitim Fakültesi, E-posta: ykabapinar@marmara.edu.tr orcid.org/ 0000-0001-6039-0096

\section{Gül TUNCEL}

Marmara Üniversitesi, Atatürk Eğitim Fakültesi, E-posta: gltuncel2@gmail.com orcid.org/0000-0002-2448-7965

Article Info

\begin{tabular}{|c|c|}
\hline Article Type & Research \& Theoretical \\
\hline Received & 01.01 .2020 \\
\hline Accepted & 08.03 .2020 \\
\hline DOI & 10.17497/tuhed.669015 \\
\hline Corresponding & Yücel KABAPINAR \\
\hline $\begin{array}{c}\text { Author } \\
\text { Cite }\end{array}$ & $\begin{array}{l}\text { Öztaşçı, C., Kabapınar, Y., Tuncel, G. (2020). Yerel tarih öğretim } \\
\text { yöntemini sosyal bilgiler dersinde kullanmak: yanıbaşında olan } \\
\text { geçmişi görmek ve duyumsamak. Turkish History Education } \\
\text { Journal, } 9 \text { (1), 66-88. DOI: } 10.17497 / \text { tuhed.669015 }\end{array}$ \\
\hline
\end{tabular}

\footnotetext{
* "Yerel Tarih Öğretim Yöntemini Sosyal Bilgiler Dersinde Uygulamaya Koymak: Bir Eylem Araştırması" başlıklı yüksek lisans tezinden üretilmiştir.
} 
Öz: Sosyal Bilgiler öğretimi alanında meydana gelen birtakım değişimler beraberinde yeni öğretim yöntem ve tekniklerinin de gündeme gelmesini sağlamıştır. Bu yöntemler arasında yer alan yerel tarih, öğrencilerin değişim ve süreklilik kavramları çerçevesinde geçmiş ve günümüz arasında bağlantı kurmalarını sağlayan bir yöntem olarak Sosyal Bilgiler Öğretim Programı́nda daha fazla yer bulmaya başlamıştır. Yerel tarih öğretim yönteminin programda yer almasına rağmen uygulamada sınırlı kaldığı ve müze/tarihi mekân gezilerinden çok da öteye gidemediği görülmektedir. Araştırmanın amacı, Sosyal Bilgiler dersinde yerel tarih öğretim yönteminin nasıl uygulanabileceğini, bu yöntemin öğrencilerin gelişimlerine katkısını ve bu süreçte yaşanılan sorunları saptamak olarak belirlenmiştir. Araştırma nitel bir çalışma olup eylem araştırması olarak modellenmiştir. Araştırmanın çalışma grubunu özel bir ortaokulun 6. sınıfında eğitim görmekte olan 22 öğrenci oluşturmaktadır. Araştırmanın uygulaması 11 haftalık zaman diliminde gerçekleştirilmiştir. Çalışmada veri toplama aracı olarak araştırmacı ve öğrenci günlükleri ve öğrenci proje ödevleri kullanılmıştır. Öğrenci proje değerlendirme açık uçlu anketinden elde edilen veriler içerik analizi ile analiz edilmiştir. Öğrenci proje ödevleri ise araştırmacı tarafından hazırlanan "Yerel Tarih Proje Değerlendirme Rubriği" kullanılarak değerlendirilmiştir. "Küçük Tarihçiler Günümüzdeki Geçmişin İzini Sürüyor: Bir Yerel Tarih Projesi" adıyla hayata geçirilen proje sürecinde verilen yerel tarih eğitiminin ardından öğrencilere birer küçük tarihçi rolü verilmiştir. Tarihi Hacı Bekir Lokumcusu (1777-Bahçekapı), Pandeli Restoran (1901-Eminönü), Kanaat Lokantası (1933-Üsküdar), Bitlis Yöresel Yemekleri, Makedon Türkleri Geleneksel Kıyafetleri, Elmalı Konak (Antalya-Elmalı'da Boyralar Köyü) öğrencilerin yerel tarih projesi kapsamında incelediği konulardan bazılarıdır. Sonuç olarak öğrencilerin araştırma öncesindeki tarih ve yerel tarih kavramına ilişkin algılarında araştırma sonrasında görece değişikliğin meydana geldiği ortaya çıkmıştır. Öğrencilerin gerçekleştirdikleri yerel tarih projelerinin başarı oranı ise \%81 olarak bulunmuştur. Araştırma bulguları sonucunda öğrencilerin yerel tarih proje süresince çeşitli zorluklar yaşadıkları, bununla birlikte yerel tarih öğretim yönteminin öğrencilerin akademik, kişisel, sosyal gelişimlerine olumlu katkısı olduğu öğrenci, veli ve araştırmacı görüşleriyle belirlenmiştir.

Anahtar Kelimeler: Yerel Tarih, Sosyal Bilgiler, Eylem Araştırması

\begin{abstract}
Certain changes in Social Studies education have brought along new methods of instruction and new teaching techniques. Together with these changes, in accordance with the new Social Studies teaching approach, a variety of methods that enable students to actively engage in learning have come into prominence. As one of these methods, local history has gained wider acceptance in the Social Studies Curriculum as a method that provides an opportunity for students to establish a connection between the past and the present within the framework of the concepts of change and continuity. It has been observed that despite being in the curriculum, local history has been limited in application and could not go beyond field trips to museums or historical places. The purpose of this study is to show how the local history teaching method can be applied in Social Studies lessons, to identify the benefits of this method in learning and to determine the problems faced during this process. This hereby is a qualitative research and has been modeled as action research. The working group comprises of 22 students that study in the 6 th grade of a private middle school. The research was conducted in an 11-week period. During this study, researcher and student journals, student projects, student project evaluation questionnaires have been used in order to collect data. Student project evaluation questionnaires were analyzed through content analysis. Data collected from researcher and student journals were analyzed through descriptive analysis. Student projects were evaluated through a 'Local History Project Assessment Rubric' that was prepared by the researcher. Following a local history education that came into being under the title "Little Historians Trace the Past in the Present: A Local History Project," students have adopted roles as little historians and completed the phases that comprised of steps such as determining a subject, making research, conduction verbal history interviews, preparing reports and exhibition. Historical Turkish Delight Manufacturer Haji Bekir (Bahçekapı, 1777), Pandeli Restaurant (Eminönü, 1901), Kanaat Restaurant (Üsküdar, 1933), local Bitlis dishes, the traditional clothes of Macedonian Turks, Elmalı Konak (Boyralar Village, Elmalı, Antalya), are some of the issues which students researched in the local history project. In conclusion, students' perception of history and local history before and after the research has shown a relative difference. It was found that the students have achieved a success rate of $81 \%$ in the local history projects that they have conducted. The research findings
\end{abstract}


show that the students have encountered various problems during the local history project, yet the local history teaching method has contributed positively to the academic, personal and social development of students as reported by the students, parents and the researcher.

Keywords: Local History, Social Studies, Action Research

\section{Extended Summary}

\section{Purpose}

Local history, the term globally used by historians, confronts us as one of the research areas of history discipline (Danacıoğlu, 2002; Caunce, 2011; Kyvig, 2011). Although history, in general, includes political and military history and its related issues, local history however mainly focuses on the issues and conceptions of the social and cultural history of a village, town or city. It means that local history concentrates mainly on local communities, historical buildings, sites, local values, traditions and so on. Certain changes in the Social Studies education programme launched in 2005 in Turkey have brought along the new methods of instruction and new teaching techniques as well (Kabapınar, 2014). Together with these changes, in accordance with the new Social Studies teaching approach, a variety of methods (such as oral history, local history, historical empathy, evidence-based history), that enable students to actively engage in learning have come into prominence. As one of these methods, local history has gained wider acceptance in the Social Studies Curriculum in Turkey as a method that provides an opportunity for students to establish a connection between the past and the present within the framework of the concepts of "change and continuity". It has been observed that despite being in the curriculum, local history has been limited in application and could not go beyond field trips to museums or historical places. The research also reveals that history teachers in Turkey have relatively limited knowledge of local history and how to apply it in classroom environments (Göç, 2008; Örten, 2008; Kabapınar ve Karakurt, 2016). Thus, the purpose of this study is to show how the local history teaching method can be applied in Social Studies lessons, to identify the benefits of this method in learning and to determine the problems faced during this process.

\section{Method}

This hereby is a qualitative research and has been modeled as an action research as applied for the purpose of implementing a new approach. The working group of the study comprises twenty-two students that study in the 6th grade of a private middle school in Istanbul, Turkey, their parents and the researcher who participated in this research as an implementing teacher. The research was conducted in an 11-week period. Following a local history education that came into being under the title "Little Historians Trace the Past in the Present: A Local History Project," students have adopted roles as little historians and completed the phases that comprised of steps such as "determining a subject", "making research", "conduction verbal history interviews", "preparing reports" and "exhibition". The students were free to study the local history topic of their choice. Historical Turkish Delight 
Manufacturer Haji Bekir (Bahçekapı, 1777), Pandeli Restaurant (Eminönü, 1901), Kanaat Restaurant (Üsküdar in İstanbul, 1933), local Bitlis dishes, the traditional clothes of Macedonian Turks, Elmalı Konak (Boyralar Village, Elmalı, Antalya), Madame Tamara Pavilion (Bostancı in İstanbul, 1903), Dalyan Fishing in Beykoz in İstanbul, Sait Faik Abasıyanık (Burgazada), Ferit Tek Street (Moda, Kadıköy), Kuzguncuk (Üsküdar) are some of the issues which the students research in the local history project. The students also received help from their families to a certain extent during the Project process.

The pre-perception, post-perception open-ended questionnaires, researcher and student journals, student projects, student project evaluation questionnaires and parent open-ended questionnaires have been used in order to collect data required. The data collected from pre-perception post-perception open-ended questionnaires, student project evaluation questionnaires, and parent open-ended questionnaires were analyzed through content analysis which is one of the qualitative analysis methods. The data collected from researcher and student journals were analyzed through descriptive analysis. Student projects were evaluated through a 'Local History Project Assessment Rubric' that was prepared by the researcher. The rubric consists of six main headings derived from the literature of local history. These are: "local history topic detention", "Using different sources", "conducting oral history interviews", "writing a research report", "exhibition and presentation process", "the other criteria". In conclusion, students' perception of history and local history before and after the research has shown a relative difference. It was found that the students have achieved a success rate of $81 \%$ in the local history projects that they have conducted.

\section{Results and Discussion}

The research findings show that most of the students have encountered various problems during the local history project, yet the local history teaching method has contributed positively to the academic, personal and social development of students as reported by the students, parents and the researcher. Most of the students have seen a different dimension of history as a subject through their local history projects that they carried out. Because the students recognized that history as a science area is not solely deal with the history of the great man (such as kings, sultans, viziers, commanders). "History from below" is of great importance as a subject to be studied in history as a contemporary approach. In this sense, the subject of history can be either local food, local folkloric clothes, the railway station or a school in a town or city. In this sense, the students realized that history does not always have to tell great stories of humanity. Participating students who completed projects also enjoyed the feeling of success as well.

\section{Giriş}

Akademik olarak tarih alanında yaşanan değişim ve gelişimlere paralel şekillenen tarih öğretiminde, oldukça uzun bir dönem geleneksel tarih anlatısı merkeze alınmıştır. Tarih 
öğretiminde ve tarih ders kitaplarında; devletleri, imparatorlukları, savaşları, önemli devlet adamlarını konu alan ezberci bir anlayış benimsenmişti. Ancak tarih öğretimindeki bu klasik bakış açısı 1970'li yıllardan itibaren sorgulanmaya ve öğrencileri "küçük bir tarihçi olarak gören Yeni Tarih" anlayışını gündeme getirmeye başlamıştı. Türkiye'de de, geç de olsa, özellikle 2000'li yılların başından itibaren eğitime ve dolayısıyla tarih öğretimine bakış açısında birtakım değişimler meydana gelmiştir (Kabapınar, 2014). Bununla birlikte okul düzeyinde yerel tarih, sözlü tarih ile birlikte birer "okul dışı öğrenme yöntemi" olarak son yıllarda daha fazla gündeme gelmeye ve Milli Eğitim Bakanlığı (MEB) öğretim programlarında kendine yer bulmaya başlamıştır (MEB, 2006; MEB, 2007; MEB, 2010; Kabapınar, 2015; Aydın ve ark., 2018; Pamuk, Pamuk, 2019).

Illkokul ve ortaokul düzeyinde tarih öğretimini kapsayan Sosyal Bilgiler dersi, amaç ve içeriği itibariyle yerel tarihin bir öğretim yöntemi olarak kullanılmasına oldukça elverişli bir ortam sağlamaktadır. Sosyal Bilgiler dersi kapsamında gerçekleştirilecek yerel tarih çalışmaları Sosyal Bilgiler anlayışına temel oluşturan özellikler olan etkili vatandaşlık, toplumsallaşma ve karşı toplumsallaşma, insan deneyimlerinin bütünlüğü, bilimsel düşünme yöntemi ile zaman boyutu konularında da çalışma yapma imkânı oluşturacaktır (Öztürk, 2007, s. 103). Yapılandırmacılık yaklaşımı çerçevesinde şekillendirilen 2005 Sosyal Bilgiler Öğretim Programı'nda doğrudan verilecek beceriler başlığı altında "değişim ve süreklilik", "tarihsel empati" ile "zaman ve kronolojiyi algılama" becerilerini kazandırmada yerel tarihin kullanılmasının önemiyle ilgili açıklamalara yer verilmiştir (MEB, 2010a; MEB, 2010b; Dere, 2018; Pamuk, Pamuk, 2019). Bu doğrultuda bir tarih öğretim yöntemi olarak yapılandırılarak kullanılan yerel tarihin Sosyal Bilgiler dersiyle öğrencilerin ulaşması hedeflenen bilgi, beceri ve değerlerin kazandırılmasında etkili olacaktır. Değişimin, gelişimin kaçınılmaz olduğu çağımızda geçmişle günümüz arasında bir köprü kurmak, daha da önemlisi genç bireylerin geçmişle gelecek arasında söz konusu köprüyü kurmalarını sağlamak gerekmektedir. Bunu başaran genç bireyler, ulusal tarih ve kültürel miras hakkında bilgi sahibi olarak kimliklerini yapılandıracak, yaşadıkları toplumun gerçek birer parçaları olacaklardır. Yerel tarih geçmişle günümüz arasında bir köprü kurmanın en başarılı yöntemlerinden biridir (Doğan, 2005; Beldağ, Balcı, 2017; Dere, 2019).

Tarihsel beceriler açısından da bakıldığında, öğrenci, tarihsel ile çağdaş olanın benzerlik ve farklılıklarını (tarihsel bir bina ile çağdaş mimari ile yapılmış bir bina; eski ve yeni oyunlar ya da oyuncaklar gibi) irdeleyerek değişim ve gelişimin anlamına ilişkin çıkarımlarda bulunabilecek ve bu değişim ve gelişimin yönüne ilişkin bakış açıları geliştirebilecektir. Benzer şekilde öğrenci, yaşam biçimi, değer yargısı, düşünüş, yeme içme, giyinme, barınma gibi noktalarda tarihsel aktörlerin neden bizden farklı olduğuna ilişkin perspektifler de geliştirebilir. Bu durumda öğrencilerde tarihsel empati ve duyarlılık düşüncesinin gelişimine katkıda bulunabilir (Dere, 2019).

Öğretim programında yer almasına rağmen yerel tarihin uygulamada kendine oldukça sınırlı yer bulduğu görülmektedir. Hatta öğretmenlerin büyük çoğunluğunun yerel tarihin ne olduğu ve nasıl kullanılacağı hakkında bilgi sahibi olmadığı, kendilerini yerel tarih konusunda yeterli bulmadıkları yapılan araştırmalarla ortaya konmuştur (Göç, 2008; Örten, 2008; Akbaba, Kılcan, 2014; Kabapınar ve Karakurt, 2016). Bununla birlikte tarih öğretimi alanında yapılan 
birçok araştırma, tarih öğretimi sırasında geçmişle güncel arasında ilişkinin yeterince kurulamadığını, öğrencilerin soyut tarih konularını somutlaştırmakta zorluk çektiklerini, ezberden öteye gidemeyen tarih öğretiminde kalıcı öğrenmenin sağlanamadığını, öğrencilerin tarih dersini sıkıcı olarak tanımladıklarını göstermektedir (Altunay, 2007; Bal, 2011; İskender, 2007; Yıldız, 2003). Bu sonuçlar, tarih öğretimi alanında anlayış değişikliğine yol açacak, tarihi ezber bilgilerden ibaret sıkıcı bir ders olmaktan kurtaracak, uygulamaya yönelik araştırmaların yapılması ihtiyacını ortaya çıkarmıştır. Aynı zamanda yerel tarihin ne olduğu ve nasıl kullanılması gerektiğini bilmeyen öğretmenlerin de konuyla ilgili yeterli donanıma sahip olasının sağlanması son derece önemlidir. Nitekim yerel tarihle ilgili gerçekleştirilen bir araştırmaya katılan öğretmenlerin yarısı yerel tarih kavramını bilmediklerini ifade etmişlerdir. Yine aynı araştırmaya katılan öğrencilerin de Malatyalı olmaktan gurur duymalarına karşın yaşadıkları il olan Malatya'yı çok da bilmedikleri sonucu ortaya çıkmıştır (Kabapınar, 2016). Bir diğer çalışmada, tarih dersi öğretmen adaylarının görev başındaki tarih öğretmenlerine göre yerel tarihin de dâhil olduğu "sınıf dışı tarih öğretimi" konusunda daha fazla farkındalık sahibi oldukları sonucu ortaya çıkmıştır (Avcı Akçalı, 2015). Tüm bu sonuçlar, yerel tarihin, Sosyal Bilgiler ve Tarih dersi kapsamında bir öğretim yöntemi olarak nasıl kullanılacağını ve yöntemin tarih öğretimine katkılarını ve uygulanması sırasında karşılaşılabilecek sorunları ve çözüm yollarını ortaya koyan çalışmalara gereksinim olduğunu ortaya koymaktadır.

Özellikle 2017 yılında ortaokul düzeyinde "Şehrimiz ...... Dersi" adlı dersin, seçmeli de olsa, ortaokul programına konulmuş olması yerel tarih ve sözlü tarih yönteminin kullanımı adına son derece önemli bir adım olmuştur (MEB, 2017; Öztürk Demirbaş, 2019). Şehir isminin köken(ler)i ve kronolojisi, üretim ve zanaat alanları, tarihi ve kültürel mekânları, tarihi şahsiyetler, sanat, edebiyat, müzik, spor, bilim, halk oyunları, geleneksel kıyafetler, yemekler, masal, efsane, destan, ninni, yöresel dil özellikleri, yerel basın ve yayın çalışmaları, şehre özgü müzik kültürü, festivaller ve kurtuluş günleri bu dersin öğretim programlarında vurgulanan kazanım ögelerinden sadece bazılarıdır.

Yerel tarih ile ilgili yapılan çalışmaların büyük çoğunluğu, yöntemin/yaklaşımın teorik arka planını literatür destekli inceleyen çalışmalar (Akçalı, 2007; Aktekin, 2010) ile eğitim paydaşlarının yerel tarihin uygulanmasına ilişkin görüşlerini saptamayı amaçlayan çalışmalar (Metin, Oran, 2014; Tunç Şahin, 2011) olarak görülmektedir. Buna karşılık lise öğrencileri ile Üsküdar'ın yerel tarihine ilişkin gerçekleştirilen proje, uygulama boyutuyla ilginç bir örnektir. Projeye 24 lise öğrencisi katılmış ve Üsküdar’ı merkeze alan 10 farklı konuyu incelemişlerdir. Liseli öğrenciler, kadim bir geçmişe sahip olan Üsküdar'daki sadaka, binek ve nişan taşlarını "Üsküdar'ın Taşları" başlığı altında incelemiş; yerel tarih kapsamında bir mezarlığın bile konu olarak seçilebileceğini de "Toprak Altında Gizemli Bir Tarih: Bülbülderesi Mezarlığı" adlı konu ile göstermişlerdir. Bu çerçevede öğrenciler inceledikleri konularda hem yazılı bir çalışma yapmışlar hem de kısa bir belgesel çekmişlerdir (Kabapınar, 2018a; Kabapınar, 2018b). Bundan başka Kimya bölümü 3. sınıf öğretmen adaylarıyla gerçekleştirilen bir yerel tarih çalışmasında da, öğrenciler birer fen bilimci olmalarına karşın alanlarının dışında konuları çalışmışlardır. Konu alanlarından bazıları; "Eminönü’ndeki Hanlar ve İşhanları AVM'lere Karşı”, "Ermeni ve Türklerde Kız İsteme ve Evlilik Gelenekleri: Ayo ve Evet'in Evrimi”, "Tarih Kokulu Semtin Tarih Kokulu Bozası: Vefa Bozacısı”, “Deniz Kenarında Bir Futbol Mabedi: Beşiktaş İnönü Stadyumu”, "Taksim'deki Hogwarts'ın Hikayesi: Özel Zapyon Rum Kız Lisesi” gibi konulardır (Kabapınar ve 
ark., 2018c). Bu çalışmada kimya öğretmen adayları, sözlü tarihi de kapsayacak şekilde merak ettikleri konuları çalışmışlar ve bildiklerinin çok ötesinde bir tarih ile karşılaştıklarını ifade etmişlerdir. Bu çerçevede araştırmanın amacı, "Sosyal Bilgiler dersinde yerel tarih öğretim yönteminin nasıl uygulanabileceğini ve ortaya çıkan proje ödevlerinin niteliğini ortaya koymaktır". Bu çalışmada araştırma sorusu; "Öğrencilerin gerçekleştirdikleri yerel tarih proje ödevlerinin niteliği nasıldır?" şeklinde belirlenmiştir.

\section{Yöntem}

Araştırma nitel araştırma yöntemi temelinde olup eylem araştırması desenine göre şekillenmiştir. Eylem araştırması türlerinin hedefleri dikkate alındığında, gerçekleştirilen araştırmada "özgürleştirici/geliştirici/eleştirici eylem araştırması" modelinin benimsenmesi uygun bulunmuştur. Özgürleştirici/geliştirici/eleştirici eylem araştırması, araştırmacının eleştirel bir bakış açış kazanmasını ve bu süreçte yeni bilgi, beceri ve deneyimlerle donanmasını amaçlamaktadır. Çalışma grubunun belirlenmesinde "amaçlı örnekleme" yöntemlerinden "ölçüt örnekleme" kullanılmıştır. Nitel araştırma geleneği içinde ortaya çıkan amaçlı örnekleme, zengin bilgiye sahip durumların seçilmesiyle derinlemesine araştırmalar yapabilme olanağı sağlamaktadır. Ölçüt örneklemedeki temel anlayış ise önceden belirlenen ölçütleri karşılayan tüm durumların çalışılmasıdır (Yıldııım ve Şimşek, 2008, s. 107-112). Gerçekleştirilen bu araştırmada ölçüt olarak katılımcıların 6. sınıf öğrencisi olmaları dikkate alınmıştır. Çünkü 6. sınıf Sosyal Bilgiler Öğretim Programı'nda (MEB, 2010b) "Birey ve Toplum" öğrenme alanında yer alan "Sosyal Bilgiler Öğreniyorum" ünitesinde "Bilimsel araştırma basamaklarını kullanarak araştırma yapar" kazanımı, ünitenin doğrudan verilecek becerisi olan "bilimsel genelleme yapma" ve doğrudan verilecek değeri olan "bilimsellik" ile yerel tarih projesi ilişkilendirilmiştir.

Araştırma kapsamında çalışmalar, araştırmacının görev yapmakta olduğu özel bir ortaokulda yürütülmüştür. Uygulama yapılan kurumun politikası gereği, öğretimde farklılığa neden olmamak için uygulamalar, okulun 89 kişi, 4 sınıftan oluşan tüm 6 . sınıf grubunda gerçekleştirilmiştir. Fakat araştırmanın nitel doğası nedeniyle, çalışmaya dâhil edilen bireylerden elde edilecek verilerin derinliği ve genişliği de göz önünde bulundurulduğunda, öğrenci sayısını sınırlandırmak için kolay ulaşılabilirliği gözönünde bulundurulan, araştırmacının derslerini yürüttüğü bir sınıf çalışma grubu olarak belirlenmiştir. Bu doğrultuda araştırmanın çalışma grubunu, İstanbul Çekmeköy'deki, özel bir kurumun 6. sınıfına devam eden 14 erkek, 8 kız olmak üzere toplam 22 öğrenci oluşturmaktadır.

Araştırma öncesinde öğrencilerin yerel tarih konusunda sahip oldukları bilgilere yönelik bir durum saptaması yapmak ve araştırma sonrasında gerçekleşecek değişimi tespit etmek amacıyla ön algı anket uygulaması yapılmıştır. Araştırmanın uygulama ve değerlendirme aşamalarına yönelik verilerin toplanması amacıyla öğrenci proje ödevleri, araştırmacı ve öğrenci günlükleri, öğrenci proje değerlendirme anketi ve veli anketi veri toplama araçları olarak kullanılmıştır. Ancak sınırıııklar nedeniyle bu araştırmada öğrenci proje ödevleri, öğrenci ve araştırmacı günlüklerinden kesitler sunulacaktır (Öztaşçı, 2017). 
Öğrenciler tarafından hazırlanan yerel tarih proje ödevlerinin niteliklerini tespit etmek amacıyla "Yerel Tarih Proje Değerlendirme Rubriği" kullanılmıştır (Bakınız Ek 1). Araştırmacı tarafından rubrik hazırlanırken birtakım temel kaynaklara ulaşılmış, rubriğin yerel tarih metodolojisine uygun olması sağlanmıştır (Caunce, 2011; Danacıoğlu, 2009; Kyvig ve 65 Marty, 2011; Thompson, 1999). Ayrıca uzman görüşleri de alınarak rubriğe son hali verilmiştir. Yerel tarih proje değerlendirme rubriği, öğrencilere dağıtılan yerel tarih proje hazırlama rehberinin son sayfasına konularak, öğrencilerin proje ödevlerinin hangi ölçütlere göre değerlendirileceğinden haberdar olmaları sağlanmıştır. Öğrenci proje ödevleri rubrikte yer alan "konu belirleme", "kaynak kullanımı", "sözlü tarih görüşmeleri", "araştırma raporu", "sergi ve sunum süreci" ile diğer başlıklı kategoriler altında yer alan ifadeler doğrultusunda değerlendirilmiştir. Böylece öğrenciler, sadece hazırladıkları proje raporu dikkate alınarak değerlendirilmemiş, proje ödevleri sırasında gerçekleştirdikleri tüm süreçler bütüncül bir bakış açısıyla değerlendirilmeye tabi tutulmuştur. Yapılan değerlendirme sonucunda 100 ile 85 arasında puan alan proje ödevleri "çok nitelikli", 84 ile 60 arasında puan alanlar "nitelikli", 59 ile 40 arasında puan alanlar "orta" ve 39 ile 0 arasında puan alan proje ödevleri ise "geliştirilmeli" olarak nitelendirilmiştir. Öğrenci proje ödevleri farklı bir araştırmacı tarafından incelenerek, puanlanmıştır. Bu puanlar, araştırmacının gerçekleştirdiği puanlamalarla karşılaştırılarak aralarındaki tutarlılık hesaplanmıştır. Yapılan hesaplamanın sonucunda öğrenci proje ödevlerinin değerlendirilmesine yönelik kodlayıcı güvenirlik değeri 0,87 olarak belirlenmiştir.

Araştırma, araştırmacının görev yapmakta olduğu özel bir ortaokulda gerçekleştirilmiştir. Öncelikle okulun Sosyal Bilgiler Bölümü’ne ve okul yöneticilerine araştırma konusu ve amacı hakkında bilgi verilmiş, uygulanması düşünülen çalışma takvimi sunulmuştur. Araştırma sürecine başlamak üzere gerekli onay ve izinler alınmıştır. Araştırmanın nitel olması nedeniyle sınırlı sayıda şube ile çalışma hedeflense de kurum politikası gereği, öğretimde farklılığa neden olmamak adına okulda bulunan tüm 6. sınıf ( 36 kız, 53 erkek olmak üzere toplam 89 kişi) öğrencileriyle toplam 4 şubede proje uygulaması gerçekleştirilmiştir. Öğrenci sayısını sınırlandırmak için ise araştırmacının derslerini yürüttüğü bir sınıf rastgele seçilerek çalışma grubu olarak belirlenmiştir.

\section{İşlem Yolu}

Öncelikle yerel tarih proje çalışmasının 6. sınıf düzeyinde gerçekleştirilmesine karar verilmiştir. 6. sınıf Sosyal Bilgiler Öğretim Programı'nda (MEB, 2010) "Birey ve Toplum" öğrenme alanında yer alan "Sosyal Bilgiler Öğreniyorum" ünitesinde "bilimsel araştırma basamaklarını kullanarak araştırma yapar" kazanımı, ünitenin doğrudan verilecek becerisi olan "bilimsel genelleme yapma" ve doğrudan verilecek değeri olan "bilimsellik" ile "Kültür ve Miras" öğrenme alanında yer alan "Ipek Yolu'nda Türkler" ünitesinin doğrudan verilecek değeri "çıkarımda bulunma" ve doğrudan verilecek değeri "kültürel mirasa duyarlılık" kapsamında söz konusu yerel tarih projesi geliştirilmiştir. Araştırmacının, okuldaki diğer Sosyal Bilgiler öğretmenleriyle yaptığı ikili görüşmeler ve ilk hafta sürece başlamadan önce öğrencilere uygulanan ön algı açık uçlu anketinin ardından elde edilen genel bulgular doğrultusunda hazırlanan eylem planı ve süreç içinde karşılaşılan sorunlara yönelik ek eylem planlarıyla 11 haftalık bir proje uygulama süreci gerçekleştirilmiştir. 
Illk hafta ön algı anketinin uygulamasının hemen ardından gerçekleştirilen "Yerel Tarih Eğitimi" ile proje süreci başlatılmıştır. Söz konusu eğitim projeye katılan her sınıf için 2 ders saati sürecek şekilde planlanmıştır. Eğitim sırasında araştırmacı tarafından hazırlanan bir powerpoint sunum kullanılmıştır. İki aşamadan oluşan eğitimin birinci aşamasında, öğrenciler yerel tarih araştırma yöntemi hakkında bilgilendirilmişlerdir. Eğitimin ikinci aşamasında ise öğrenciler, gerçekleştirecekleri "Küçük Tarihçiler Günümüzdeki Geçmişin İzini Sürüyor: Bir Yerel Tarih Projesi" adı verilen yerel tarih projesinin aşamaları hakkında detaylı olarak bilgilendirilmişlerdir. Bu aşamada araştırmacı tarafından öğrencilere proje süreçleri boyunca yol göstermek amacıyla hazırlanan "Proje Rehberi" dağıtılmıştır. Projenin bütünü, "Konu belirleme aşaması", Kaynakların toplanması", "Sözlü tarih görüşmelerinin yapılması", "araştırma raporunun hazırlanması" ve "projelerin sergilenmesi" aşamalarından oluşmaktadır. Bu aşamalar aşağıda özetlenmiştir.

\section{Konu Belirleme Aşaması (1 hafta)}

Birinci aşama olan "Konu Belirleme" için öğrencilere 1 hafta süre verilmiştir. Seçecekleri konunun mutlaka özgün bir yerel tarih konusu olması gerektiği üzerinde durulmuştur. Öğrencilere, yerel tarih denildiğinde, herkesin öncelikli olarak aklına gelen konuları seçmemeleri, çok bilindik ve duyulmuş konulardan uzak durmaları gerektiği hatırlatılmıştır. Çalışma grubunda yer alan öğrencilerin seçtikleri ve öğretmenleri tarafından onaylanan çalışma konuları aşağıdaki gibidir.

Tablo 1

Öğrenciler ve Çalışma Konuları

\begin{tabular}{|l|l|l|l|}
\hline Kod & Yerel Tarih Çalışma Konusu & Kod & Yerel Tarih Çalışma Konusu \\
\hline Ö1 & Maslak Atatürk Oto Sanayii (1970) & Ö12 & Makedon Türkleri Geleneksel Kıyafetleri \\
\hline Ö2 & Rüstempaşa Camii (Tahtakale) & Ö13 & Vefa Bozacısı (Fatih-Vefa) \\
\hline Ö3 & Samandıra Sarayı (Damatris Sarayı) & Ö14 & Kanaat Lokantası (1933-Üsküdar) \\
\hline Ö4 & Kaytaz Böreği (Hatay) & Ö15 & Hacı Bekir Lokumcusu (1777-Bahçekapı) \\
\hline Ö5 & Kurukahveci Mehmet Efendi (Eminönü) & Ö16 & İnci Profiterol \\
\hline Ö6 & Cihangir Camii & Ö17 & Titus Tüneli (Adana) \\
\hline Ö7 & Vize (Kırklareli) & Ö18 & Elmalı Konak (Antalya-Elmalı Köyü) \\
\hline Ö8 & St. Pierre Kilisesi (Hatay - Antakya) & Ö19 & Bitlis Yöresel Yemekleri \\
\hline Ö9 & Pandeli Restoranı (1901-Eminönü) & Ö20 & Göynük Mantısı \\
\hline Ö10 & Beykoz Şişe Cam Fabrikası & Ö21 & Sinop Nokulu \\
\hline Ö11 & Pişmaniye (İzmit) & Ö22 & Beykoz'da Dalyan Balıkçılı̆ı \\
\hline
\end{tabular}

Çalışma grubunda yer almayan fakat yerel tarih projesini gerçekleştiren diğer sınıflarda da ilgi çekici yerel tarih konuları araştırılmıştır. Öğrencilerin çalıştığı konulara şunları örnek verebiliriz;

- Bir yere özgü pastane, şekerci vb. mekânlara örnekler: Baylan Pastanesi/Kadıköy 1923, Hicipoğlu Şekercisi/Eminönü 1745, Şekerci Cafer Erol/Kadıköy 1807, Vefa Bozacısı/1876, Taşdelen Su/1592,

- Yöresel yemek kültürüne örnekler: Dible/Karadeniz yöresi, Kesme Aşı/Sivas yöresi, Beş Parmak yemeği/Kazakistan yöresi, Erzincan/Kemaliye yemek kültürü 
- Semt, mahalle, cadde, sokak, meydan vb. alanlara örnekler: Kuzguncuk Semti/Üsküdar, Yeldeğirmeni Mahallesi/Kadıköy, Hâkimiyet-i Milliye Caddesi/Üsküdar

- Tarihsel binalara örnekler: Madam Tamara'nın Köşkü/Bostancı 1903, Zafia Rizi Anı Evi/Polonezköy 1881, Sarıcalar Köşkü/Moda 1903, Kandilli Köyü Evleri, Arap Camii/Karaköy, Aya Yorgi Kilisesi/Büyükada, Büyükada Saat Kulesi, Eski Moda İskelesi,

- Bir yere özgü tarihsel kişiliklere örnekler: Sait Faik Abasıyanık/Burgazada, Can Yücel/Kuzguncuk, Şifa Eczanesi/Mehmet Hidayet Derman (Safranbolu'nun ilk eczacısı)

- Üretim yerlerine örnekler: Turhal Şeker Fabrikası/Tokat 1930, SEKA Kâğıt Fabrikası/Kocaeli 1936

- Yöresel kültüre örnekler: Adana/Kozan'a özgü konuşma, Konya kına geceleri, Kastamonu Zeybeği

\section{Kaynak Toplama Aşaması (2 hafta)}

Konu seçimini tamamlayan öğrenciler, projenin ikinci aşaması olarak kaynak toplamaya başlamışlardır. Çalışma konuları çerçevesinde güvenilir kaynak niteliği taşıyan kitap, internet ve görsel materyallerden yararlanarak kaynak toplayan öğrenciler süreç içinde takip edilmiş, gerekli durumlarda öğrencilere yönlendirmelerde bulunulmuştur. Kaynak toplama aşaması yaklaşık 2 haftalık sürede tamamlanmıştır.

\section{Sözlü Tarih Görüşmeleri Aşaması (3 hafta)}

Sözlü tarih görüşmelerini yapmaları için öğrencilere 3 hafta süre tanınmıştır. Öğrenciler, kaynak toplama aşamasında elde ettikleri verilerden de yararlanarak görüşme sorusu hazırlamışlardır. Sorularını öğretmen onayı için getirdiklerinde, söz konusu soruların bir kısmının sözlü tarih görüşmelerinde kullanılabilecek nitelikte olmadığı tespit edilmiştir. Araştırmacı kendi günlüğüne anılan sorun ile ilgili olarak şu notları almıştır.

\section{Şekil 1. Araştırmacı Günlüğünden Bir Kesit}

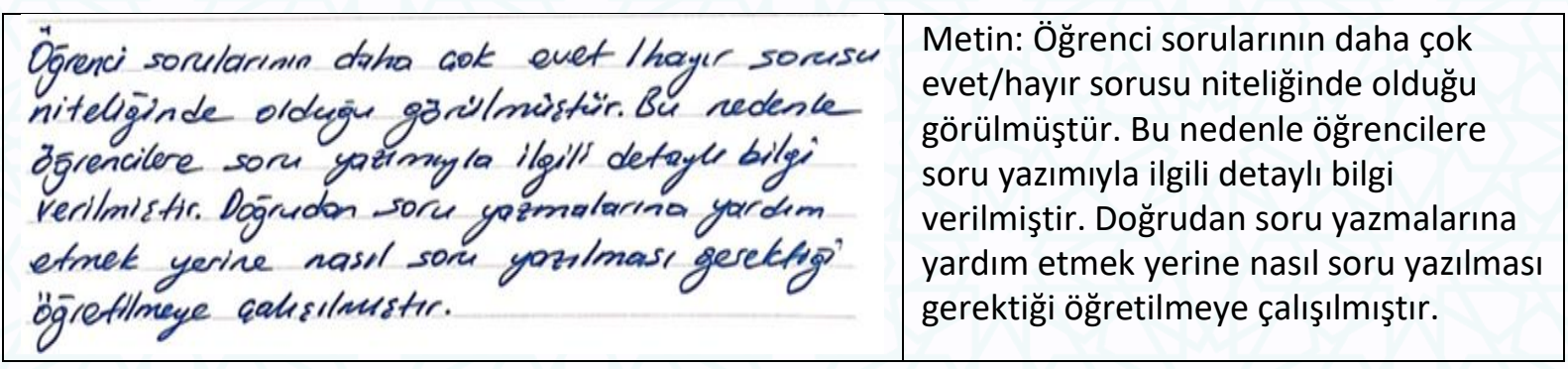

Bu durumu çözmek amacıyla araştırmacı tarafından hazırlanan ek eylem planı çerçevesinde, öğrencilere soru yazma teknikleriyle ilgili bir sunum yapılmıştır. Sunumun ardından, öğrencilerin hazırladıkları yeni sorular tekrar değerlendirilmiştir. Tıpkı konu seçimlerinde olduğu gibi hazırladıkları sözlü tarih görüşme soruları onaylanan öğrenciler çalışmalarının bir sonraki basamağına geçmişlerdir. Seçtikleri konu hakkında bilgi alabilecekleri 4 kişi belirleyen öğrenciler, sözlü tarih görüşmelerini yapmak üzere bu kişilerden randevu almışlardır. Kaynak kişilerin belirlenmesinde olanaklı olduğu kadar 40-50 yaş üstü kişilerin tercih edilmesine dikkat edilmiştir. Genel olarak öğrenciler, her kaynak kişiye hazırladıkları aynı soruları yöneltmişlerdir. Çalışma konusu olarak dükkân ya da çeşitli tarihi mekânları seçen öğrenciler ise buranın sahibi ya da çalışanlarıyla da görüşme yapmışlardır. Ön hazırlıklarını tamamlayan öğrenciler belirledikleri kaynak kişilerle sözlü tarih görüşmelerini 
gerçekleştirmişlerdir. Öğrencilerin tamamına yakını görüşmelerini video ve ses kaydıyla kayıt altına almıştır. Bazı kaynak kişilerin izin vermemesi üzerine birkaç öğrenci görüşmelerini not tutarak kayıt altına almıştır.

\section{Rapor Hazırlama Aşaması (2 hafta)}

Bu aşamada öğrenciler ulaştıkları tüm kaynaklardan topladıkları bilgileri analiz ederek araştırma raporlarını hazırlamışlardır. Yönerge paralelinde ödevler; kapak, içindekiler bölümü, önsöz, ana bölüm, sözlü tarih görüşmeleri, sonsöz, kaynakça, kişi kaynakçası bölümlerinden oluşmuştur. Öğrencilere raporlarına son hallerini vermeleri için sözlü tarih görüşmelerini gerçekleştirdikten sonra iki hafta süre tanınmıştır. Bu haftanın sonunda ise öğrenciler raporlarını öğretmenlerine teslim etmişlerdir.

\section{Sergi Hazırlık ve Sergileme Aşaması (3 hafta)}

Öğrencilerin, proje raporu teslimlerini gerçekleştirmelerinin ardından, projenin son aşaması olan sergi hazırlıklarına başlanmıştır. Poster sunumlarını, kendilerine dağıtılan $70 \mathrm{x}$ $100 \mathrm{~cm}$ boyutundaki kartona, sergi hazırlık rehberinin içinde yer alan şablonuna uygun şekilde hazırlamışlardır. Proje sergisi hakkında bilgilendirmek üzere, tüm 6. sınıf velilerine "Proje Sergisi Veli Bilgilendirme Mektubu" ve proje sergisi e-davetiyesi e-posta yoluyla iletilmiştir. Bu sürece ilişkin fotoğraflara aşağıda yer verilmiştir.

Şekil 2. Sergi Hazırlıkları ve Sergiden Kesitler
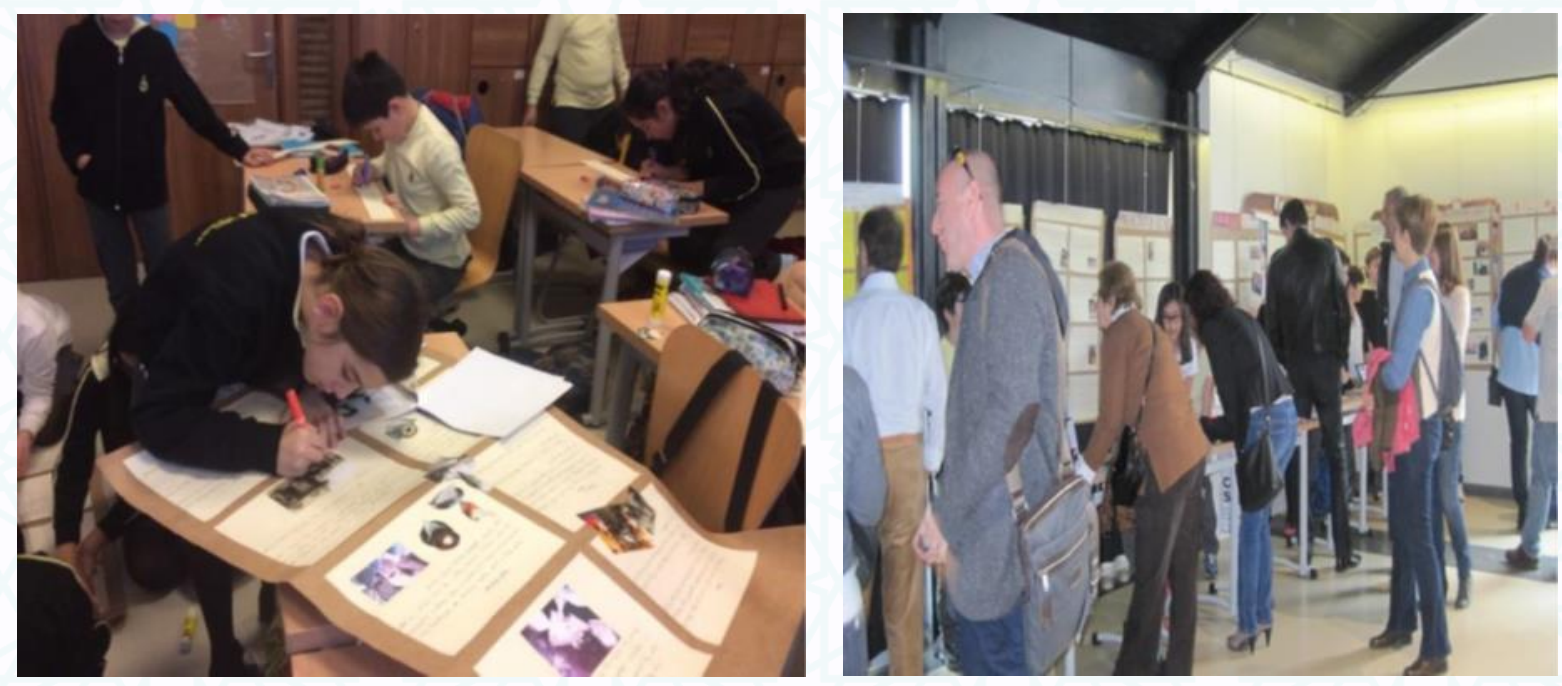

Bulgular

\section{Araştırma Sorusu: Öğrencilerin Gerçekleştirdikleri Yerel Tarih Proje Ödevlerinin Niteliği Nasıldır?}

Öğrenciler tarafından gerçekleştirilen yerel tarih projeleri, araştırmacı tarafından hazırlanan "Yerel Tarih Proje Değerlendirme Rubriği" ile değerlendirilmiştir (Bkz. Ek 1). Bu rubrik, yerel tarih projelerinin konu belirleme, kaynak kullanımı, sözlü tarih görüşmeleri, araştırma raporu, sergi ve sunum süreci ile projenin diğer adımlarına yönelik olmak üzere toplam 6 kategoriden oluşmaktadır. Araştırmacı, rubrik doğrultusunda öğrencilerin projelerini 
"Çok Nitelikli", "Nitelikli", "Orta" ve "Geliştirilmeli" olarak belirlenen ölçütlere göre sınıflandırmıştır.

Tablo 1

Yerel Tarih Öğrenci Projelerinin Nitelikleri

\begin{tabular}{|c|c|c|c|}
\hline Nitelik & Puan & Projelerin İsimleri & Sayı \\
\hline $\begin{array}{l}\text { Çok } \\
\text { Nitelikli }\end{array}$ & $85-100$ & $\begin{array}{l}\text { Kurukahveci Mehmet Efendi (Eminönü), Vize (Kırklareli), Pandeli } \\
\text { Restaurant (Eminönü), Pişmaniye (İzmit), Vefa Bozacısı (Fatih- } \\
\text { Vefa), Kanaat Lokantası (Üsküdar), İnci Profiterol (Beyoğlu, Titus } \\
\text { Tüneli (Adana), Bitlis Yöresel Yemekleri, Beykoz'da Dalyan } \\
\text { Balıkçılığı }\end{array}$ & 10 \\
\hline Nitelikli & $60-84$ & $\begin{array}{l}\text { Rüstempaşa Camii (Tahtakale), Kaytaz Böreği (Hatay), Cihangir } \\
\text { Camii (İstanbul - Cihangir) } \\
\text { St. Pierre Kilisesi (Hatay - Antakya), Beykoz Şişe Cam Fabrikası, } \\
\text { Makedon Türkleri Geleneksel Kıyafetleri, Hacı Bekir Lokumcusu } \\
\text { (1777 - Bahçekapı), Elmalı Konak (Antalya-Elmalı Boyralar Köyü), } \\
\text { Sinop Nokulu }\end{array}$ & 9 \\
\hline Orta & $40-59$ & Maslak Atatürk Oto Sanayi (1970), Göynük Mantısı & 2 \\
\hline \multirow[t]{2}{*}{ Geliştirilmeli } & $0-39$ & Samandıra Yazlık Saray (Damatris Sarayı) & 1 \\
\hline & & Toplam & 22 \\
\hline
\end{tabular}

"Yerel Tarih Proje Değerlendirme Rubriği”ne göre projelerin 10’unun "Çok Nitelikli", 9'unun "Nitelikli", 2'sinin "Orta" ve 1'inin "Geliştirilmeli" olarak değerlendirildiği görülmektedir. Ayrıca öğrenciler tarafından gerçekleştirilen yerel tarih projelerinin, projeleri değerlendirmede kullanılan rubrikten elde edilen sonuçlara göre başarı oranlarının \%81 olduğu belirlenmiştir. Aşağıda öğrencilerin gerçekleştirdikleri yerel tarih projelerinden örnekler, öğrencilerin proje etkinliklerinden kesitler ve çalışmalarını belgeleyen fotoğraflara da yer verilerek ayrıntılı olarak açıklanmaya çalışımıştır.

\section{Örnek Öğrenci Projesi 1: Pandeli Restoran Yerel Tarih Projesi (Çok Nitelikli)}

"Çok nitelikli" projeler arasında değerlendirilen Pandeli Restoran Yerel Tarih Projesi'ni gerçekleştiren Ö9, çalışmalarını zamanında ve yönergeye uygun olarak gerçekleştirmiştir. Ö9 yaptığı ön araştırma sonrasında ebeveynlerinin de yönlendirmesiyle proje konusu olarak İstanbul Eminönü'nde bulunan Pandeli Restoran'ı çalışmaya karar vermiş ve konusunu öğretmenine onaylatmıştır. Öğrenci, bu süreci öğrenci günlüğünde şu şekilde dile getirmiştir:

\section{Şekil 3. GN9 (Günlük Sayfa 2)}

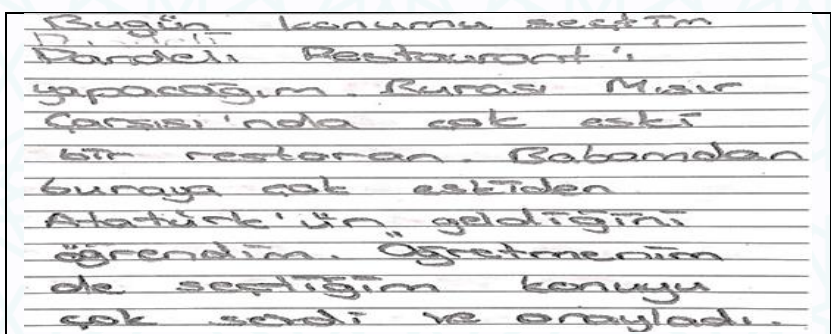

Metin: Bugün konumu seçtim, Pandeli Restaurant'l yapacağım. Burası Mısır Çarşısı'nda çok eski bir restoran. Babamdan buraya çok eskiden Atatürk'ün geldiğini öğrendim. Öğretmenim de seçtiğim konuyu çok sevdi ve onayladı.

Ö9, günlüğünün bu sayfasında seçtiği konudan bahsederken buranın bulunduğu yer hakkında da bilgi vermekte ve Mısır Çarşısı'nda olduğunu ifade etmektedir. Özellikle öğrencinin seçtiği konunun eski bir geçmişe sahip olduğuna vurgu yaptığı görülmektedir. Yine 
konu bulma sürecine babanın da dahil olması öğrenci-veli etkileşimi adına son derece önemlidir. Çünkü öğrencilerin gerçekleştirdikleri bu tarz yerel tarih projelerinde, belirli bir oranda aile/veli katkısı yerel tarih ikliminin aile/ev ortamında yaşaması ve aile içi paylaşımın yapılması adına önem taşımaktadır. Ö9'un proje raporunun kapak sayfası ve içindekiler bölümü aşağıda görülmektedir.

Şekil 4. Pandeli Restoran Yerel Tarih Proje Raporu Kapağı ve İçindekiler Bölümü
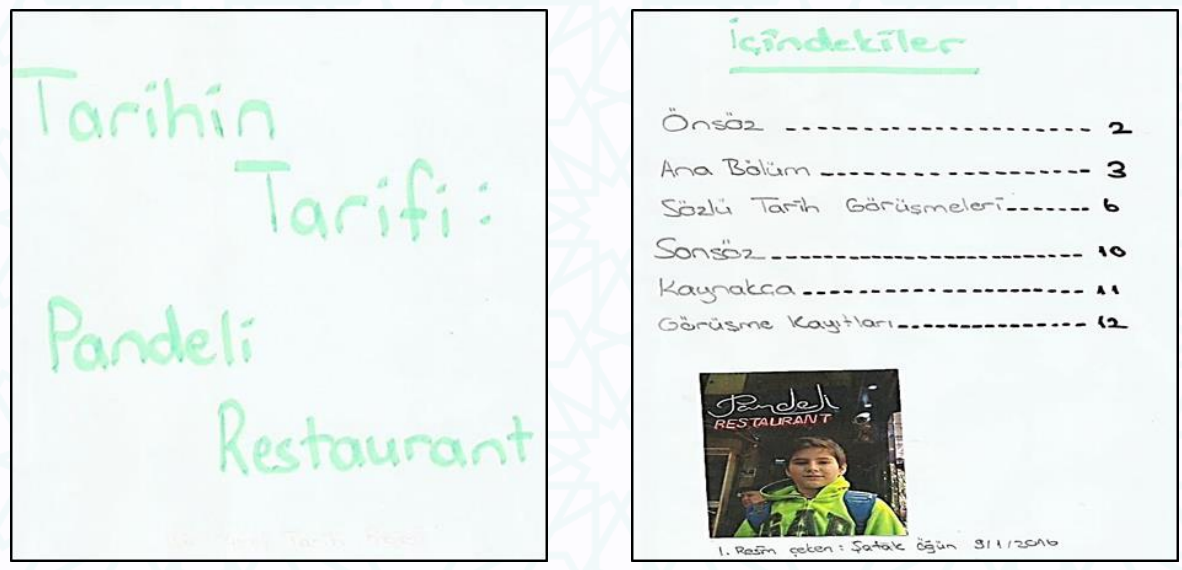

Öğrencinin raporunda ilk olarak, çalışmasına verdiği başlık dikkat çekmektedir. Öğrenci projesini, proje raporunun kapağında "Tarihin Tarifi: Pandeli Restoran" olarak adlandırmıştır. Çalışma konusunu tarih, bu konu hakkında yaptığı yerel tarih çalışmasını bu konunun tarifi olarak nitelendiren öğrenci çalışmasını bu şekilde adlandırmayı uygun görmüştür. Ö9'un hazırladığı içindekiler sayfası incelendiğinde ise proje raporunda önsözün ardından ana bölüm, sözlü tarih görüşmeleri, son söz, kaynakça, kişi kaynakçası ve son olarak da sözlü tarih görüşme kayıtlarını içeren CD’nin bulunduğu bölümlere yer verdiği görülmektedir.

Öğrenci araştırma raporunun ana bölümünde araştırma konusuna ait detaylı bilgi vererek, bu yerin tarihi geçmişine ve günümüzdeki durumu ile hizmet anlayışına değinmektedir. Öğrenci, ana bölümde verdiği bilgilere yönelik kaynakça gösterme kurallarına uygun şekilde metin içi kaynakça göstermiştir. Bu durum öğrencinin akademik dürüstlük ilkesine uygun şekilde bilimsel araştırma basamaklarını uyguladığını göstermektedir. Öğrencinin araştırma raporunun ana bölümünün ilk iki sayfası aşağıda sunulmuştur.

Şekil 5. Pandeli Restoran Yerel Tarih Proje Raporundan İki Sayfa
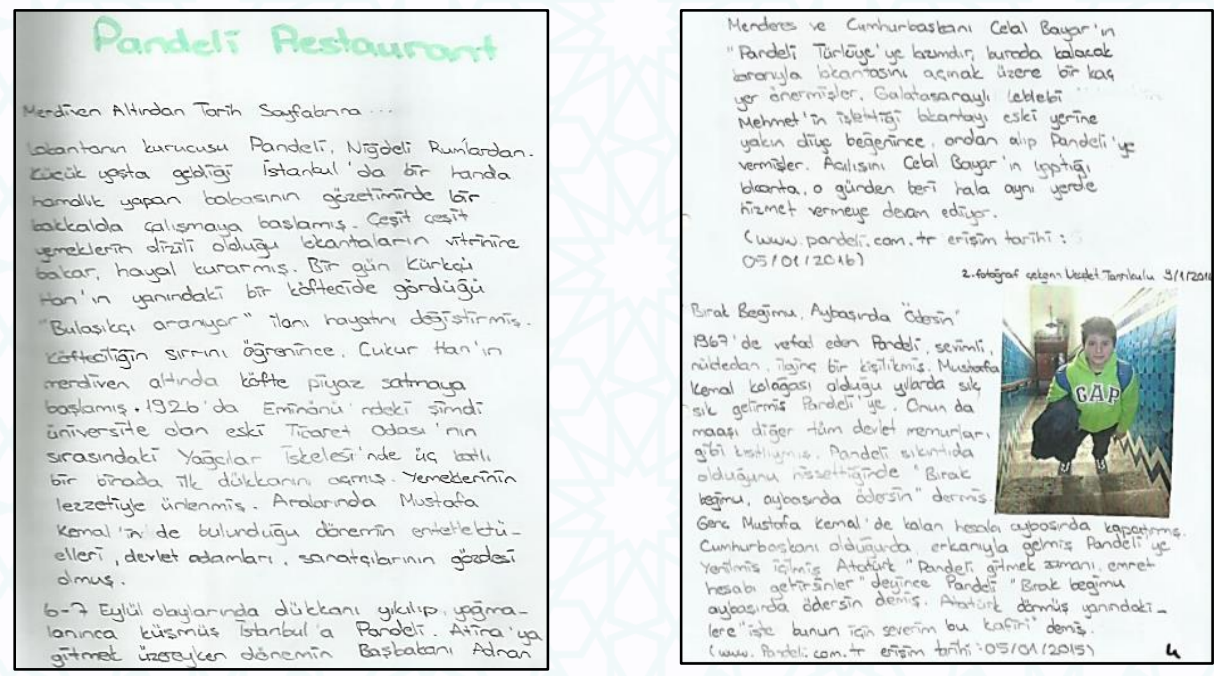
Ö9'un araştırma raporunun ana bölümüne "Merdiven Altından Tarih Sayfalarına" şeklinde başladığı dikkat çekmektedir. Bu ifadelerle öğrencinin, araştırma konusunun tarihselliğine vurgu yaptığı görülmektedir. Yine bu bölümde öğrenci, lokantanın kurucusu Pandeli'nin İstanbul'a geldikten sonra Pandeli Restoran'ı nasıl açtığına ve restoranın bugünkü yerine gelene kadar geçirdiği süreçlere dair bilgiler vermektedir. Ayrıca "Aralarında Mustafa Kemal'in de bulunduğu dönemin entelektüelleri, devlet adamları, sanatçıların gözdesi olmuş" ifadeleriyle de restoranın o dönemde tercih edilen, önemli bir konumda olduğunun üzerinde durmuştur. Öğrenci ana bölümünün ilerleyen kısımlarında, tarihe tanıklık eden restoranın 67 Eylül Olayları sırasında nasıl etkilendiğinden bahsetmiştir. Ö9 tarafından Niğdeli Rumlardan olan Pandeli'nin restoranının bu olaylar sırasında yağmalandığı, bu olaydan etkilenen Pandeli'nin Atina'ya gitmek üzereyken dönemin Başbakanı Adnan Menderes ve Cumhurbaşkanı Celal Bayar tarafından vazgeçirilerek, dükkânını bugün hala hizmet verdiği Eminönü'ndeki yerine taşıdığı bilgileri verilmiştir.

Bu bilgilerin ardından ana bölümünde, Mustafa Kemal ve Pandeli arasında geçen bir anekdota yer veren öğrenci raporunun içeriğini zenginleştirmiştir. Ana bölümün son sayfasına "Aş̧̧ılar 45 Yıllık" ifadeleriyle başlayan öğrenci hem konuya dikkat çekmiş hem de araştırma konusunun tarihselliğine bir kez daha vurgu yapmıştır. Ardından Pandeli Restoran'ın çalışanlarının kolay kolay değişmediğini ifade ederek, günümüzde restoranın mutfağının 69 yıl Pandeli Restoran'da çalışan aş̧̧ı İsmail Demir'in yetiştirdiği Süleyman Çelik ve Nazım Telli'ye emanet olduğunu söylemiştir. Bu iki ismin restoranda uzun yıllardır görev yaptığını da ifade eden öğrenci zaman içinde restoranın sağladığı sürekliliği de gözler önüne sermiştir.

Şekil 6. Yerel Tarih Proje Raporu Ana Bölümü ile Sözlü Tarih Görüşme Sürecinden Kesit

\begin{tabular}{|c|c|}
\hline 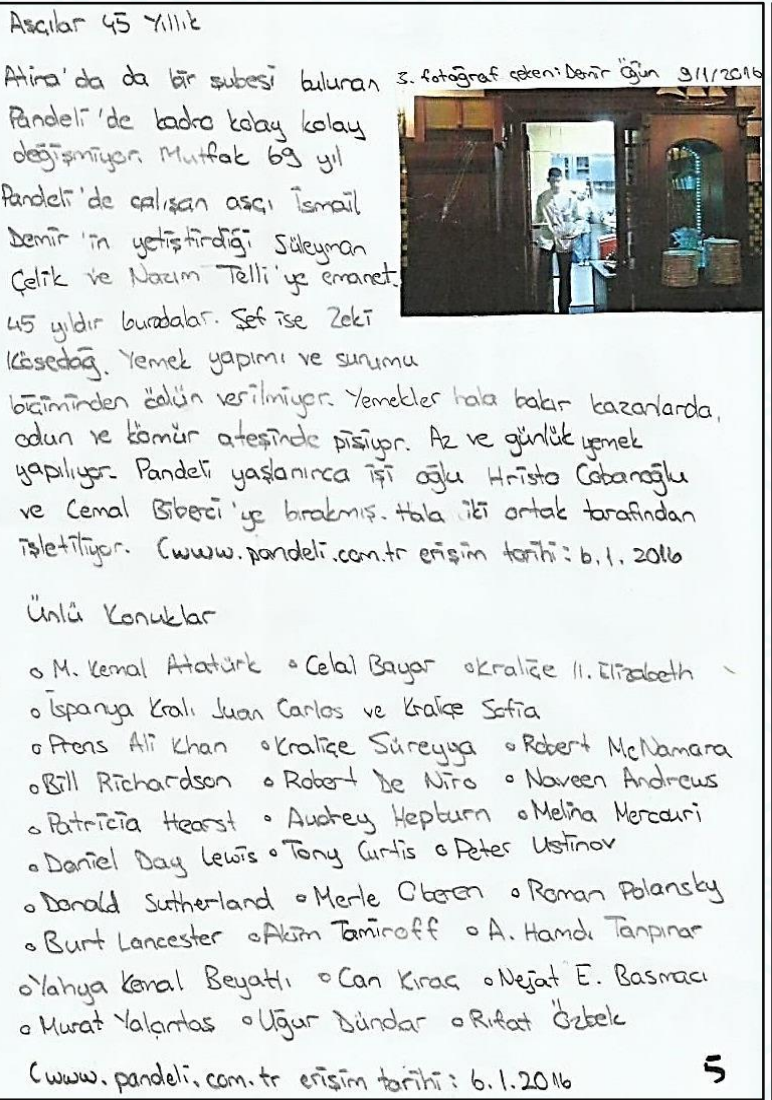 & 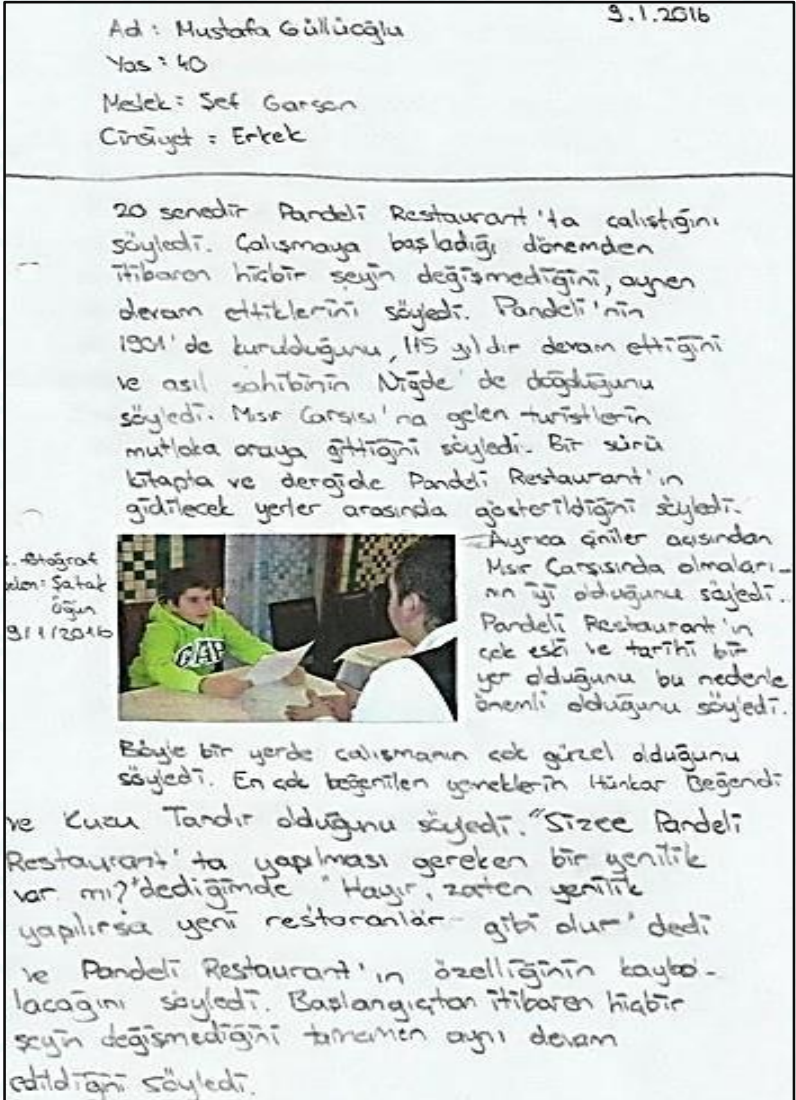 \\
\hline
\end{tabular}


Ö9, raporunun ana bölümünde restoranın yemek yapımı ve sunumunda sahip olduğu anlayışı geçmişten günümüze kadar sürdürdüğünü "Yemek yapımı ve sunumu biçiminden ödün verilmiyor. Yemekler hala bakır kazanlarda, odun ve kömür ateşinde pişiyor. Az ve günlük yemek yapılıyor" ifadeleriyle sürekliliği ortaya koymuştur. Son olarak ise Pandeli Restoran'da yemek yiyen ünlülerden isimlere yer vermiştir. Öğrencinin ana bölümünü restoranı ziyareti sırasında çektiği fotoğraflarla zenginleştirildiği ve rapor boyunca metin içi kaynakça gösterdiği görülmektedir.

Öğrenci yerel tarih araştırma konusuna yönelik kaynak toplamak ve inceleme yapmak amacıyla Pandeli Restoranı ziyaret etmiştir. Bu ziyareti sırasında da projenin bir diğer basamağı olan sözlü tarih görüşmelerini gerçekleştirmiştir. Öğrenci yaptığı ön çalışmanın ardından sözlü tarih görüşmeleri sırasında kaynak kişilere yönelteceği soruları hazırlamış ve öğretmenine onaylatmıştır. Öğrenci, sözlü tarih görüşme sorularını hazırlama sürecinden günlüğünde şu şekilde bahsetmiştir:

Şekil 7. GN9 (Günlük Sayfa 5)

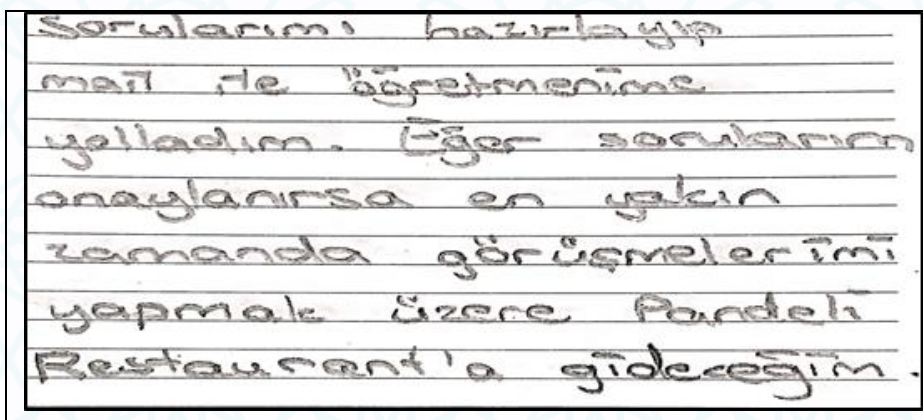

Metin: Sorularımı hazırlayıp mail ile öğretmenime yolladım. Eğer sorularım onaylanırsa en yakın zamanda görüşmelerimi yapmak üzere Pandeli Restaurant'a gideceğim.

Ö9, günlüğünde bahsettiği gibi öğretmenine sorularını onaylattıktan sonra, sözlü tarih görüşmelerini yapmak üzere Pandeli Restoran'a gitmiştir. Bu ziyaret sırasında sözlü tarih görüşmelerini gerçekleştirmiş ve görüşme yaptığı kişilere ait bilgileri araştırma raporunun kişi kaynakçası bölümüne eklemiştir. Öğrenci restoranda 28 yıldır çalışan baş aş̧̧ı ve aşçı yardımcısı, 20 yıldır çalışan şef garson ve 10 yıldır restoranın müşterisi olan İş Bankası Müzesi Müdürü ile görüşmelerini gerçekleştirmiştir. Şekil 6 'da öğrencinin, restoranın şef garsonuyla gerçekleştirdiği sözlü tarih görüşmesine ait metin görülmektedir.

20 yıldır restoranda çalışan şef garson, öğrenciye, 1901 yılında kurulan restoranın tarihi hakkında bilgi verdikten sonra, restoranın Mısır Çarşısı'na gelen turistlerin uğrak yeri olduğunu, birçok kitap ve dergide Pandeli Restoran'ın gidilmesi gereken yerler arasında gösterildiğini, tarihi açıdan önemli olduğunu ifade etmiştir. Öğrencinin yönelttiği "Sizce Pandeli Restoran'da yapılması gereken bir yenilik var mı?" sorusuna kaynak kişinin, yenilik yapılırsa yeni restoranlar gibi olacağını ve restoranın özelliğini kaybedeceğini, başlangıcından beri Pandeli Restoran'da değişim yaşanmadığını ifade etmesi tarihsel öneme sahip yerleri koruma bilincinin önemini vurgulaması açısından dikkate değerdir. Bu aynı zamanda sözlü tarih için önemli bir kavram olan sürekliliği de işaret etmektedir.

Öğrenci proje raporunun sonsözünde gerçekleştirdiği yerel tarih araştırmasını hem öğretici hem de eğlenceli olarak nitelendirmiştir. Çalıştığı konuya ait çok fazla kaynak bulamadığını ifade etmiştir. Araştırma raporunun kaynakça kısmı incelendiğinde, Pandeli 
Restoran'ın internet sitesi, restorana ait dergi ve menü ile Yüzyıllık Markalar Derneği'ne ait Yüzyıllık Hikâyeler internet sitesinden yararlanıldığı görülmektedir. Çalışılan yerel tarih konusunun özgünlüğü dolayısıyla öğrencinin yararlandığı kaynakların sayısının araştırma için yeterli olduğu söylenebilir. Öğrenci araştırma ve raporlama sürecini tamamladıktan sonra çalışmasını, proje sergisinde sunmak üzere poster sunum haline getirmiştir.

Şekil 8. Pandeli Restoran Yerel Tarih Projesine Ait Poster Sunum
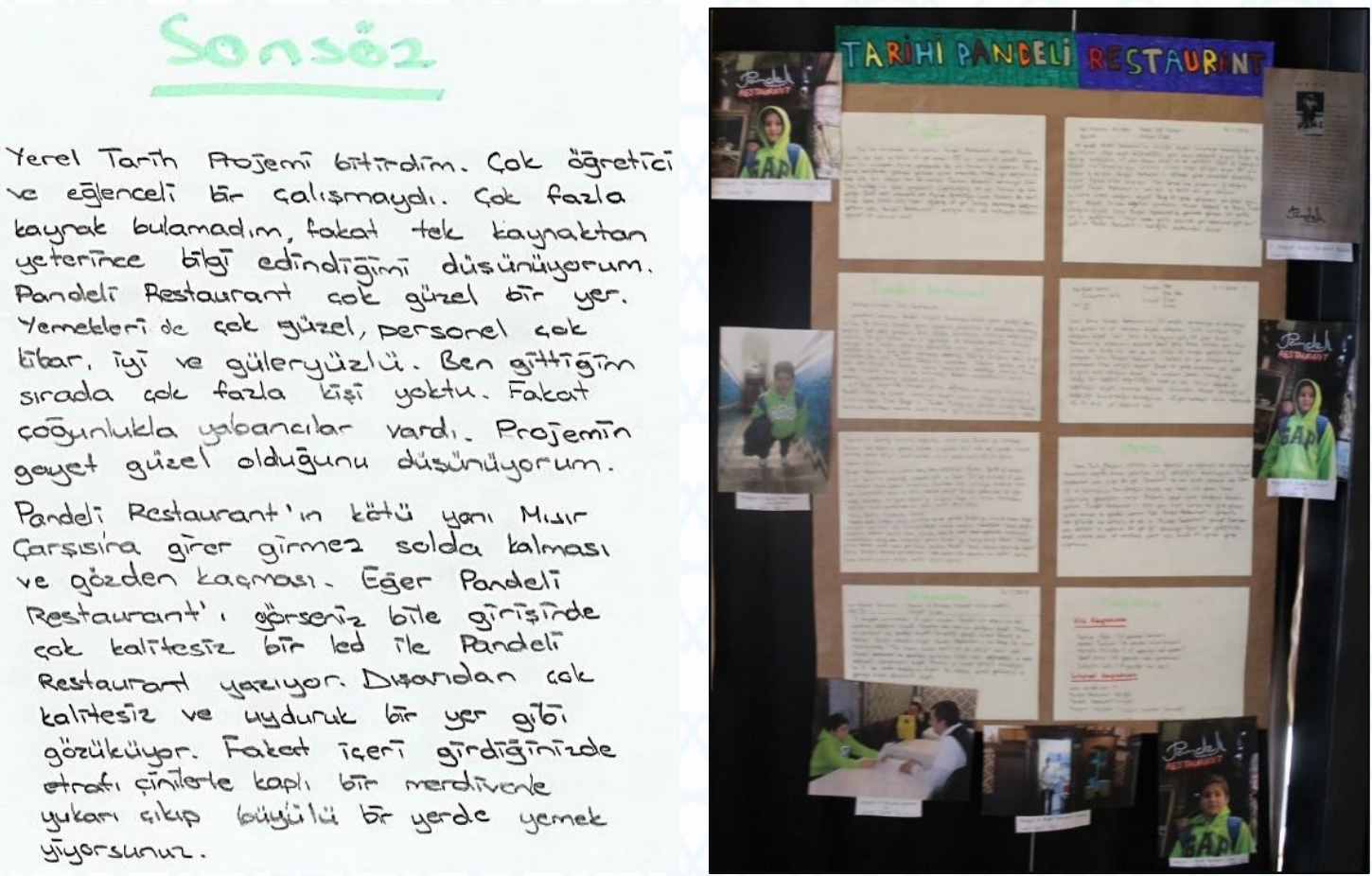

Öğrencinin poster sunumunu, "Sergi Hazırlık Rehberi"nde yer alan kriterlere uygun şekilde hazırladığı görülmektedir. Ayrıca öğrenci başlık, isimlik, önsöz, ana bölüm, sözlü tarih görüşmeleri, sonsöz, kaynakça ve kişi kaynakçası bölümlerinden oluşan posterini, restoranı ziyareti sırasında çektiği fotoğraflarla görsel açıdan zenginleştirmiştir. Sergi sırasında ziyaretçilere projesi hakkında bilgi veren öğrenci, projenin tüm aşamalarını eksiksiz ve özenli bir şekilde gerçekleştirerek küçük tarihçi rolünü hakkıyla yerine getirmiştir.

\section{Örnek Öğrenci Projesi 2: Bitlis Yöresel Yemekleri Yerel Tarih Projesi (Çok Nitelikli)}

Ö19'un gerçekleştirdiği yerel tarih projesinin konusu Bitlis yöresel yemekleridir ve çok nitelikli projeler arasında değerlendirilmiştir. Öğrenci proje raporunun önsözünde, bu konuyu seçme nedeninin babasının ailesinin Bitlisli olması olduğunu söylemiştir. Öğrenci, babasının ailesinin 1973 yılında Bitlis'ten İstanbul'a geldiğini, buna rağmen Bitlis yemek kültürünü sürdürdüklerini, özellikle özel günlerde ve aile toplantılarında mutlaka yöresel yemeklerin pişirildiğini ifade etmiştir. Öğrencinin bu yemek kültürünün aileyi bir arada tutan bir öğe olarak değerlendirmesi kültürel öğelerin insanları bir arada tutma gücünü gördügünü ortaya koymaktadır. Öğrenci Bitlis yöresel yemeklerinin zor ve zaman alıcı yemekleri olduğunu, kadınların mutfaktaki yeterliliklerinin bu yemekleri yapabilme durumlarıyla değerlendirildiğini söyleyerek bu kültürdeki kadının konumuna da işaret etmektedir. Aynı zamanda yemeklerin yapımında bir araya gelinerek yardımlaşıldığı öğrencinin üzerinde durduğu bir diğer konu olmuştur. 
Öğrenci projesine "Doğu'dan Bir Yemek Masalı: Bitlis Yöresel Yemekleri” adını vermiştir. Öğrenci, tuttuğu günlükte, kaynak olarak kullandığı bir kitaptan esinlenerek projesine bu ismi koyduğunu söylemiştir. Proje raporunun ana bölümünde ise öğrenci tarafından Bitlis yemek kültürüne ait genel bilgi verilmiştir. Bu bölümde öğrenci yararlandığı çeşitli kaynaklardaki bilgilerin yanı sıra aile ve akraba yaşantısı sırasında konuya ait edindiği gözlemlerine de yer vermiştir. Bitlis yemek kültürüne ait detaylı bilginin yer aldığı genel bilgi bölümünde, yemeklerde kullanılan malzemelerden, yeme şekline kadar çeşitli bilgilere de yer verilmiştir.

Şekil 9. Bitlis Yörel Yemekleriyle İlgili Ödevin Kapağı ve İlk Sayfası
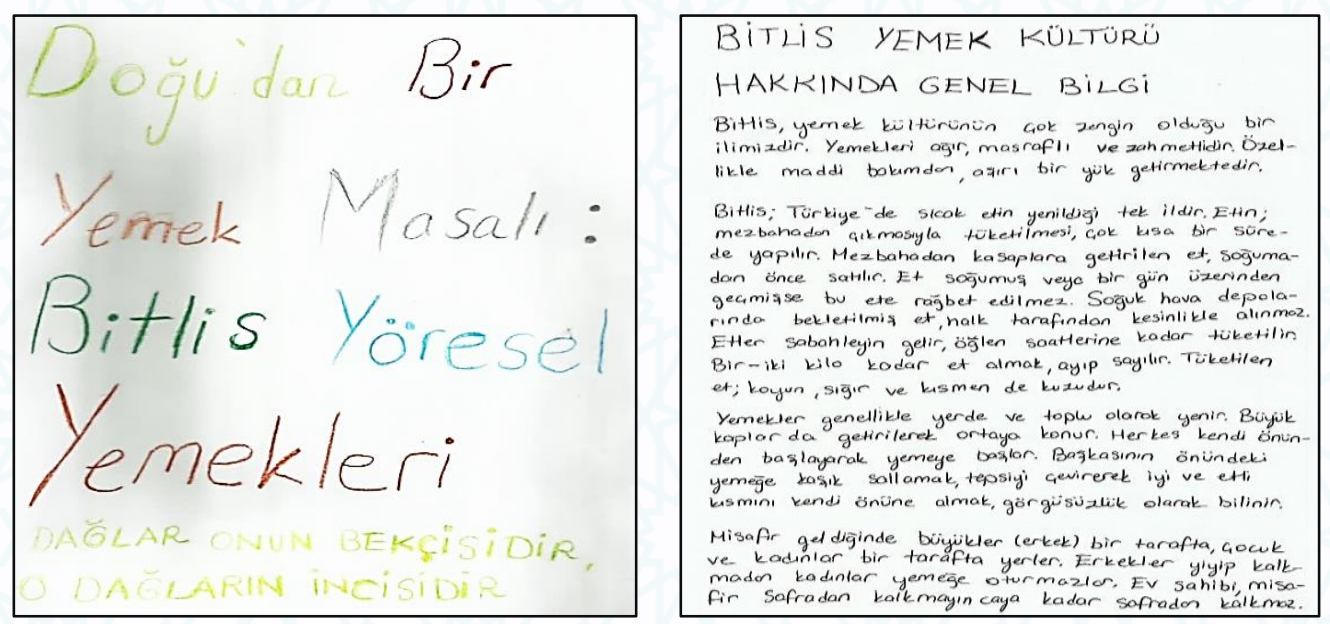

Ana bölümün devamında Bitlis yemek kültürüne ait olan ve öğrenci tarafından belirlenen üç yemek olan ayran aşı, ciğer taplaması ve şirin kaygana tarifleri ayrıntılı bir şekilde verilmiştir. Yemeklerin görsellerinin de yer aldığı tarifler kaynak gösterilerek yazılmıştır. Öğrenci yerel tarih araştırma raporunun ana bölümünün ardından, gerçekleştirdiği sözlü tarih görüşmelerinde elde ettiği bilgileri sunmuştur. Görüşmeler 60 , 66, 83 yaşlarında Bitlis doğumlu üç ev hanımı ve yine ev hanımı olan 54 yaşında, aileye gelin olarak gelen Kayseri doğumlu bir aile üyesiyle gerçekleştirilmiştir. Sözlü tarih görüşmeleri için konuya hâkim olan uygun kaynak kişilerin seçildiği görülmektedir. Öğrenci gerçekleştirdiği sözlü tarih görüşmelerini kayıt altına almış, ardından görüşme analiz formlarını kullanarak yazıya geçirmiştir.

Şekil 10. Bitlis Yöresel Yemek Tarifi ve Görüşmeden Bir Örnek
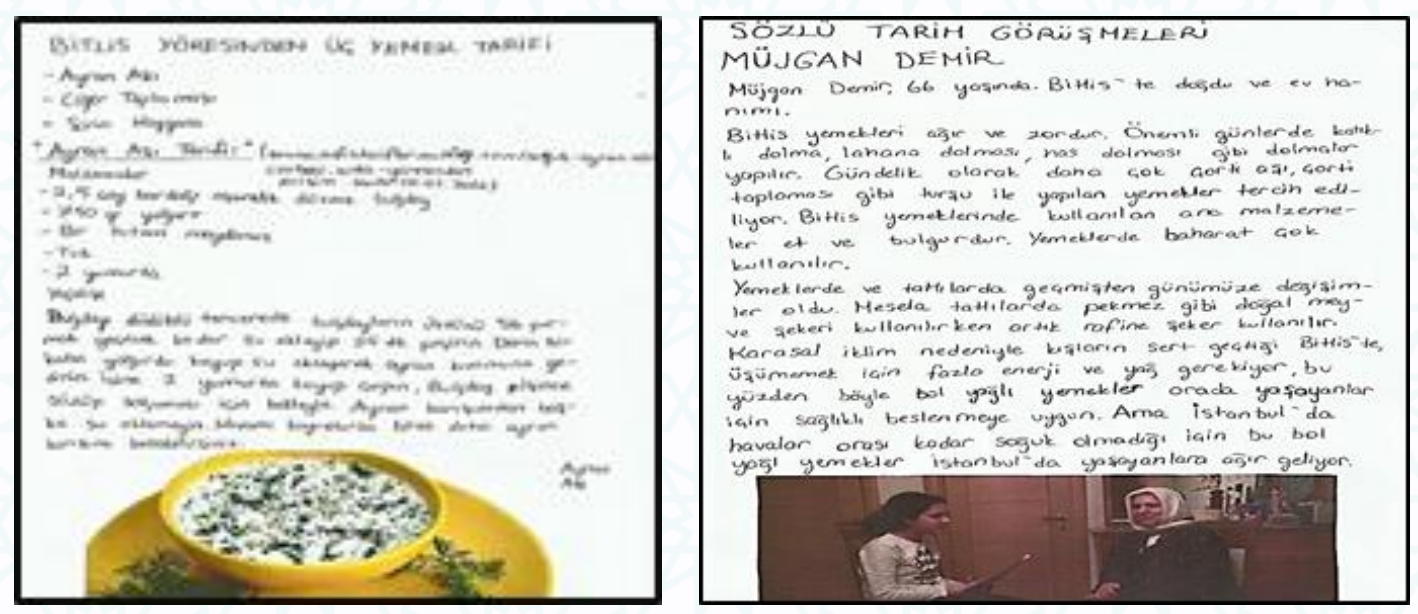
Öğrencinin görüşme metni incelendiğinde, kaynak kişi tarafından kendisine Bitlis yemek kültürüne ait genel özelliklerin anlatıldığı, Bitlis mutfağının geçmişten günümüze geçirdiği değişimlerden bahsettiği görülmektedir. Öğrencinin görüşme metni incelendiğinde, kaynak kişi tarafından kendisine Bitlis yemek kültürüne ait genel özelliklerin anlatıldığı, Bitlis mutfağının geçmişten günümüze geçirdiği değişimlerden bahsettiği görülmektedir. Öğrenci yaptığı bu görüşmenin ardından günlüğüne şunları kaydetmiştir;

Şekil 11. GN19 (Günlük Sayfa 7)

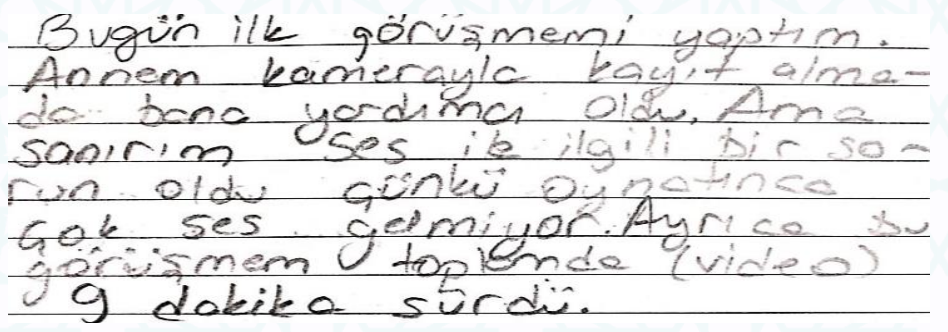

Metin: Bugün ilk görüşmemi yaptım. Annem kamerayla kayıt almada bana yardımcı oldu. Ama sanırım ses ile ilgili bir sorun oldu çünkü oynatınca çok ses gelmiyor. Ayrıca bu görüşmem toplamda (video) 9 dakika sürdü.

Öğrenci, raporunun son sözünde ise dikkat çekici ifadeler kullanmıştır. Özellikle annesinin ailesi ile babasının ailesinin yemek kültürünü ve bu kültürün zaman içindeki değişiminden bahsetmiştir. Her iki ailenin de 1970'li yıllarda İstanbul'a göç ettiklerini, babasının ailesinin Batman'dan, annesinin ailesinin ise Çanakkale'den geldiklerini söyleyen öğrenci, annesinin ailesinin de kendine özgü bir yemek kültürü olduğuna değinmiştir. Annesinin ailesinin yemek kültürünün, İstanbul'a geldikten sonra aslını kaybettiğini ve farklı yemeklerle değiştiğini söyleyen öğrenci, babasının ailesine ait yemek kültürünün aslını kaybetmeden varlığını sürdürdüğünü vurgulamıştır. Bu duruma da Doğu’nun geleneklerine bağlılığını ve aile bağlarının kuvvetli olmasını gerekçe olarak göstermiştir. Aynı zamanda görüşme yaptığı dört kişinin de yemek tariflerini hemen hemen aynı şekilde vermeleriyle de Bitlis yöresel yemeklerinin geçmişten günümüze fazla değişime uğramadan devamlılığını sürdürdüğü yargısına ulaşmıştır. Söz konusu ifadeleriyle değişim ve süreklilik kavramları üzerine düşünmemizi sağlayan öğrenci, yerel tarihin birbirinden etkilenen iki öğesi olan mekân ve insanın birbirine ne denli bağlı olduğunu da ortaya koymaktadır.

Şekil 12. Ödevin Sonsöz'ü ve Poster Sunum Hali

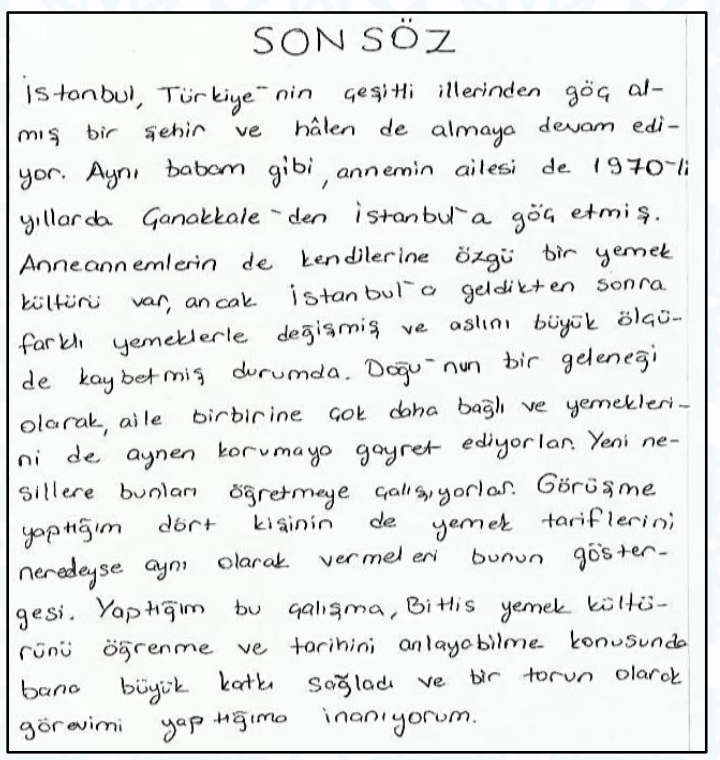

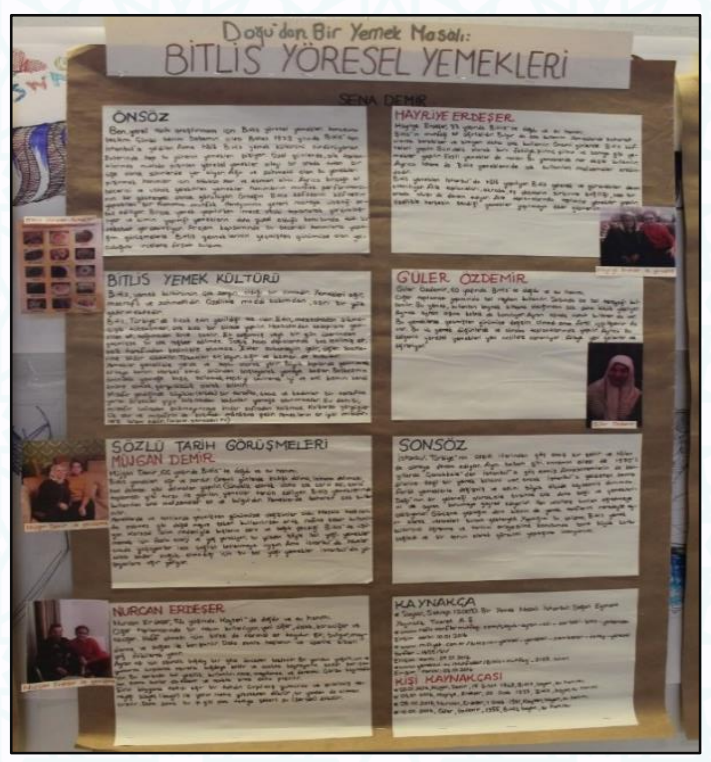


Öğrenci son sözünü bitirirken, yaptığı yerel tarih araştırmasının Bitlis yemek kültürünü öğrenme ve tarihini anlayabilme konusunda kendisine büyük katkı sağladığını ifade etmiştir. Aynı zamanda aile köklerini ilgilendiren böyle bir konu çalışmanın kendisinde ailesine karşı görevini yerine getirdiği duygusu uyandırdığını da eklemiştir. Öğrencinin projesinde kullandığı kaynaklar incelendiğinde, çalışmaya uygun kaynakların bilimsel araştırma ilkelerine uygun olarak kullandığı görülmüştür. Öğrenci araştırma ve raporlama sürecini tamamladıktan sonra çalışmasını, proje sergisinde sunmak üzere poster sunum haline getirmiştir. Sergi sırasında poster sunumunun başında duran öğrenci, gelen ziyaretçilere yerel tarih araştırma konusu hakkında bilgi vermiştir. Aynı zamanda oluşturduğu Bitlis yöresel yemekleri menüsünden örnekler getiren öğrenci, sergi süresince ziyaretçilere getirdiği yemeklerden ikram etmiştir.

\section{Sonuç}

Araştırma bulguları sonucunda Sosyal Bilgiler dersinde bir öğretim yöntemi olarak kullanılan yerel tarihe ait öğrenci ürünlerinin niteliğinin yüksek olduğu görülmüştür. Araştırmacı tarafından hazırlanan "Yerel Tarih Projesi Değerlendirme Rubriği"ne göre projelerin 10'u "Çok Nitelikli", 9'u "Nitelikli", 2'si "Orta" ve 1'i "Geliştirilmeli" olarak değerlendirilmiştir. Rubriğe dayalı olarak yapılan puanlama sonucunda, yerel tarih projelerinin başarı oranlarının \% 80'in üzerinde olduğu belirlenmiştir. Öğrencilerin geliştirdiği yerel tarih projelerinin nitelik olarak yüksek olduğu tespit edilmiştir. Bu durum fırsat verildiğinde öğrencilerin birer küçük tarihçi gibi çalışabildiklerini, alana ait metodolojiyi öğrenerek uygulayabildiklerini göstermektedir. Bu şekilde gerçekleştirilen yerel tarih uygulamaları öğrenciye birçok açıdan da fayda sağlamaktadır (Kabapınar, 2014; Yeşilbursa, 2015). Araştırmada yerel tarih öğretim yöntemi kapsamında gerçekleştirilen proje uygulamasının öğrencilerin akademik, kişisel ve sosyal gelişimleri üzerinde katkıları olduğu belirlenmiştir. Yerel tarih proje uygulamasının öğrencilerin akademik gelişimine katkısının; araştırma/veri toplama, düşünme, sorgulama, yorumlama, yazma, rapor tutma, soru sorma, soru üretme, bilgi edinme, tarihe çok yönlü bakma, tarih bilinci, yaşayarak öğrenme şeklinde olduğu ortaya çıkarılmıştır. Bu sonuç, alanyazındaki yerel tarih öğretiminin öğrencilerin akademik gelişimlerine olumlu katkısı olduğu yönünde birçok araştırma ile benzerlik göstermektedir. Nitekim Işık'ın (2002), Şahin'in (2011) ve Avcı Akçalı'nın (2015) araştırmalarının sonuçları, yerel tarih öğretimine yönelik yapılan uygulamaların öğrencilerin akademik başarılarına olumlu etkisi olduğu bulgusuyla örtüşmektedir. Projenin öğrencilerin kişisel gelişimlerine katkıları öğrenci, veli ve araştırmacı görüşleriyle sorumluluk, pes etmeme, proje yapma becerisi, merak etme, düzenli olma, tasarlama, öğrenme, dinleme, sanatsal yön, farklı bir meslek seçme düşüncesi oluşturma şeklinde belirlenmiştir.

Araştırma öncesinde tarih bilimine ve yerel tarih kavramına dair algıları siyasi ve askeri tarih eksenli olan öğrencilerin araştırma sonrasında tarih ve yerel tarih kavramı algılarına yönelik ifadelerinde yerel tarihin kapsamına giren konu ve kavramları da dile getirdikleri tespit edilmiştir (Kabapınar, 2018a). Bu anlamda yerel tarih araştırmasına katılan öğrencilerin tarih bilimine yükledikleri anlam ve işlevin genişlediğini söylemek yanlış olmayacaktır. 


\section{Kaynakça}

Akbaba, B., Kılcan, B. (2014). Sosyal bilgiler öğretmen adaylarının sözlü tarih çalışmalarına yönelik tutumları. İlköğretim Online, 13(3), ss. 746-758.

Aktekin, S. (2010). The place and importance of local history in the secondary history education. Journal of Theory and Practice in Education, 6 (1), ss. 86-105.

Akçalı, A. A. (2007). Yerel tarih ve tarih eğitimine katkısı (Yayımlanmamış Yüksek Lisans Tezi). Dokuz Eylül Üniversitesi Eğitim Bilimleri Enstitüsü, İzmir.

Altunay Şam, E. (2007). Amasya eğitim fakültesinde farklı bölümlerde okuyan öğretmen adaylarının tarih dersine ilişkin tutumları. Gazi Eğitim Fakültesi Dergisi. 27 (3) ss.1-19.

Avcı Akçalı, A. (2015). Kuram ve uygulamada sınıf dışı tarih öğretimi algısı: Öğretmen ve aday öğretmen görüşleri. Eğitim ve Bilim, 40, ss. 117-137.

Aydın, M., Dündar, R., Kaya, F. (2018). Yerel tarih etkinlikleriyle sosyal bilgiler öğretimi. R. Sever, M. Aydın, E. Koçoğlu (Eds.), Alternatif Yaklaşımlarla Sosyal Bilgiler Eğitimi, s. 503516. Ankara: PegemA.

Bal, M. S. (2011). Türkiye'de tarih öğretiminin sorunları ve çözüm yolları konusunda öğretmen adayı ve öğretmen görüşlerinin karşılaştırılması. Mustafa Kemal Üniversitesi Sosyal Bilimler Enstitüsü Dergisi, 8 (15), ss.371-387.

Beldağ, A., Balcı, M. (2017). Sosyal bilgiler öğretiminde sözlü tarih yönteminin kullanımı: Nitel bir çalışma. Uluslararası Türk Eğitim Bilimleri Dergisi, 5(9), ss. 176-189.

Caunce, S. (2011). Sözlü tarih ve yerel tarihçi. İstanbul: Tarih Vakfı Yurt.

Danacıoğlu, E. (2009). Geçmişin izleri yanıbaşımızdaki tarih için bir kılavuz. İstanbul: Tarih Vakfı.

Dere, ì. (2018). Sosyal bilgiler öğretim programlarında (2005 ve 2017) sözlü tarih. Milli Eğitim Dergisi, 47 (219), ss. 33-56.

Dere, í. (2019). Kanıt temelli öğrenmeyle ilişkisi bağlamında sözlü tarihe bakmak. Y. Kabapınar (Ed.) Kimlik Belirleyen Derslerde Kanıt Temelli Öğrenme. Ankara: PegemA.

Doğan, Y. (2015). Okul dışı sosyal bilgiler öğretiminde sözlü tarih. A. Şimşek, S. Kaymakcı (Ed.), Okul Dışı Sosyal Bilgiler Öğretimi, s. 113-141. Ankara: PegemA.

Göç, N. (2008). Yerel tarih konularının sosyal bilgiler derslerinde uygulanması; karşılaşılan güçlükler ve çözüm önerileri (Yozgat örneği) (Yayımlanmamış Yüksek Lisans Tezi). Gaziosmanpaşa Üniversitesi Sosyal Bilimler Enstitüsü, Tokat.

Işık, H. (2002). Yerel tarih konularının sosyal bilgiler (6. sınıf) programı tarih üniteleri ile ilişkilendirilmesine yönelik bir uygulama: Pasinler örneği (Yayımlanmamış Yüksek Lisans Tezi). Gazi Üniversitesi Eğitim Bilimleri Enstitüsü, Ankara. 
İskender, P. (2007). Öğretmen adaylarının tarih dersine ilişkin tutumları. Kastamonu Eğitim Dergisi, 15 (2), ss. 631.638.

Kabapınar, Y. (2014). Kuramdan uygulamaya sosyal bilgiler öğretimi. Ankara, PegemA.

Kabapınar, Y. (2015). Sosyal bilgiler öğretim programlarında okul dışı öğrenmeye bakmak: 'Bize Her Yer Sınıf, Bize Her Yer Öğrenme Ortamı' , A. Şimşek, S. Kaymakçı (Ed.), Okul Dışı Sosyal Bilgiler Öğretimi, s. 43-73, Ankara: PegemA.

Kabapınar, Y., Karakurt, F. (2016). Yerel tarih, sosyal bilgiler/tarih öğretim programlarında yer almalı mıdır? "Malatyalı olmak" ile "Malatya'yı bilmek" aynı şey midir? Turkish History Education Journal, 5 (2), ss. 437-463.

Kabapınar, Y. (2018a). (Editör) Genç tarihçiler Üsküdar'ın yerel tarihini yazıyor belgeselini çekiyor. İstanbul: Hat Baskı Sanatları.

Kabapınar, Y. (2018b). Gençler Üsküdar'ın tarihini yazıyor, belgeselini çekiyor: Tüm süreçleriyle bir yerel ve sözlü tarih projesi. Turkish History Education Journal, 7 (2) ss. 532-554.

Kabapınar, Y., Çelik, A., Ubuz, B., Uyar, L. (2018c). Kimya öğretmen adaylarının yerel/sözlü tarihle imtihanı: Periyodik cetvelden öte bir yaşam da varmış. V. Uluslararası Tarih Eğitimi Sempozyumu (Tam Metin Bildiriler E-Kitap), ss. 499-511.

Kyvig, D. ve Marty, M. (2011). Yanıbaşımızdaki tarih. İstanbul: Tarih Vakfı Yurt.

MEB. (2006). Sosyal bilgiler öğretim programı (6. ve 7. sınıf). Ankara: MEB.

MEB. (2007). Tarih dersi öğretim programı (9. sınıf). Ankara: MEB.

MEB. (2010a). Sosyal bilgiler dersi 4 ve 5. sınıflar öğretim program ve kılavuzu. http://ttkb.meb.gov.tr/www/ogretim-programlari/icerik/72 adresinden edinildi (22.01.2015).

MEB. (2010b). Sosyal bilgiler dersi 6. ve 7. sınıflar öğretim program ve kılavuzu. http://ttkb.meb.gov.tr/www/ogretim-programlari/icerik/72 adresinden edinildi (22.01.2015).

MEB. (2017). Şehrimiz ..... dersi öğretim programı (Ortaokul 5, 6, 7, ve 8. sınıflar), Ankara.

Metin, B. ve Oran, M. (2014). Illköğretim sosyal bilgiler öğretmenlerinin ders içi yerel tarih konusundaki faaliyetleri. Uşak Üniversitesi Sosyal Bilimler Dergisi, 7(1), ss. 204-216.

Örten, H. (2008). Yerel tarih konularının sosyal bilgiler üniteleri ile ilişkilendirilmesine yönelik bir çalışma (Tokat örneği) (Yayımlanmamış Yüksek Lisans Tezi). Gaziosmanpaşa Üniversitesi Sosyal Bilimler Enstitüsü, Tokat.

Öztaşçı, C. A. (2017). Yerel Tarih öğretim yöntemini sosyal bilgiler dersinde uygulamaya koymak: bir eylem araştırması (Yayımlanmamış Yüksek Lisans Tezi). Marmara Üniversitesi Eğitim Bilimleri Enstitüsü, İstanbul.

Öztürk, C. (2007). Küreselleşme ve Bilgi Çağında Sosyal Bilgiler Öğretimi. A. Oktay ve P. Ö. Unutkan (Ed.), illköğretimde Alan Öğretimi, ss.101-142. İstanbul: Morpa Kültür. 
Öztürk Demirbaş, Ç. (2019). Dersimiz: Şehrimiz. T. Çelikkaya, Ç. Öztürk Demirbaş, T. Yıldırım, H. Yakar (Ed.). Sosyal Bilgiler Öğretimi I, s. 401-443. Ankara: PegemA.

Pamuk, A., Pamuk, İ. (2019). Sosyal bilgilerde yerel tarih. T. Çelikkaya, Ç. Öztürk Demirbaş, T. Yıldırım, H. Yakar (Ed.). Sosyal Bilgiler Öğretimi II, s. 433-453. Ankara: PegemA.

Şahin, C. T. (2011). Yerel tarih uygulamalarının başarıya ve öğrenci ürünlerine etkisi. Uluslararası Sosyal Araştırmalar Dergisi, 4 (16), ss. 444-462.

Thompson, P. (1999). Geçmişin sesi. İstanbul: Tarih Vakfı Yurt.

Tunç Şahin, C. (2011). Yerel tarih uygulamalarının başarıya ve öğrenci ürünlerine etkisi. Uluslararası Sosyal Araştırma Dergisi, (16), ss. 453-462.

Yeşilbursa, C. C. (2015). Okul dışı sosyal bilgiler öğretiminde yerel tarih. A. Şimşek ve S. Kaymakçı (Ed.), Okul Dışı Sosyal Bilgiler Öğretimi, s. 143-169. Ankara: PegemA.

Yıldırım, A. ve Şimşek, H. (2008). Sosyal bilimlerde nitel araştırma yöntemleri. Ankara: Seçkin.

Yıldız, Ö. (2003). Türkiye'de tarih öğretiminin sorunları ve çağdaş çözüm önerileri. Erciyes Üniversitesi Sosyal Bilimler Enstitüsü Dergisi, 15, ss.181-190. 
Ek 1: Proje Değerlendirme Rubriği

\section{PROJEM NASIL DEĞERLENDIRILECEK?}

Değerli öğrenciler projenizin tüm süreçleri aşağıda yer alan "Değerlendirme Rubriği" kullanılarak değerlendirilecek ve puanlanacaktır. Çalışmalannızı gerçekleştirirken bu ölçütlere göre değerlendirileceğinizi göz önünde bulundurmanızın çalışmanıza fayda sağlayacağını hatırlatmak isterim.

\section{PROJE DEĞERLENDIRME RUBRIĞi}

\begin{tabular}{|c|c|c|c|c|c|}
\hline Kategoriler & Ifadeler & $\begin{array}{l}\text { Nitenllkal } \\
\text { (3 puan) }\end{array}$ & $\begin{array}{c}\text { Iy } \\
\text { (2 puan) }\end{array}$ & $\begin{array}{c}\text { Gelligtirimell } \\
\text { (1 puan) }\end{array}$ & $\begin{array}{c}\text { Yapilmadi } \\
\text { (0 puan) }\end{array}$ \\
\hline \multirow{2}{*}{ 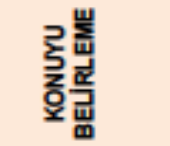 } & Özgūn bir "yerel tarih" konusu seçilmiştir. & & & & \\
\hline & Proje konusu öğretmene onaylatılmıştır. & & & & \\
\hline \multirow{4}{*}{ 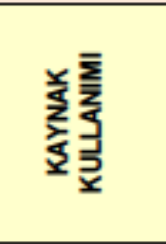 } & $\begin{array}{|lcccc|}\begin{array}{l}\text { Kitap. internet, dergi vb. farklı kaynaklardan } \\
\text { yararlanılmıștır. }\end{array} & \text { val } \\
\end{array}$ & & & & \\
\hline & \begin{tabular}{|lllll}
$\begin{array}{l}\text { Yeterli gōrsel materyal } \\
\text { kullanılmıștır. }\end{array}$ & (fotoğraf, & resim vb.) \\
\end{tabular} & & & & \\
\hline & $\begin{array}{l}\text { Yararlanilan kaynaklardan yapilan doǵrudan alıntılar } \\
\text { "alıntı yapma ilkelerine" uygun yapilmıstır. } \\
\end{array}$ & & & & \\
\hline & $\begin{array}{l}\begin{array}{l}\text { Kullanilan kaynaklar "kaynakça" gösterme kurallarına } \\
\text { uyggun yazılmıștır. }\end{array} \\
\end{array}$ & & & & \\
\hline \multirow{6}{*}{ 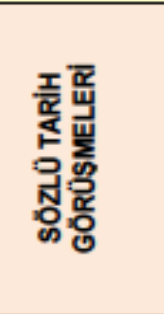 } & $\begin{array}{l}\text { Kaynak kişilere sorulan sorular araştırmanın amacına } \\
\text { ungundur. }\end{array}$ & & & & \\
\hline & 50 yașının üstünde en az 4 kișiyle görūșme yapılmıștır. & & & & \\
\hline & $\begin{array}{l}\text { Görūş̧me sırasında, amaca uygun kamera kaydı } \\
\text { yapılmıștır. }\end{array}$ & & & & \\
\hline & $\begin{array}{l}\text { Kaynak kişilerle fotoğraf çektirilmiş ve araştırma } \\
\text { raporuna eklenmiştir. }\end{array}$ & & & & \\
\hline & Görūșme kayıtları "CD"ye yazdırılmıștır. & & & & \\
\hline & 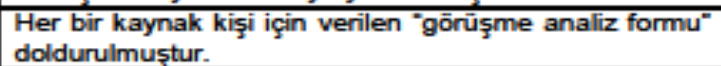 & & & & \\
\hline \multirow{7}{*}{ 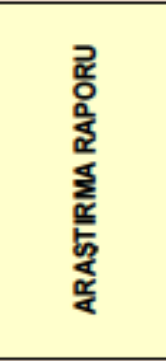 } & $\begin{array}{l}\text { Rapor kapağnna konuyla ilgiji yaratıcı bir başlık } \\
\text { yazılmıștir. }\end{array}$ & & & & \\
\hline & $\begin{array}{l}\text { Sōzlü tarih görñ şmelerinden elde edilen veriler raporda } \\
\text { uygun peluilde kullanulmışır. }\end{array}$ & & & & \\
\hline & 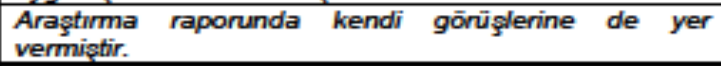 & & & & \\
\hline & Hazırlanan raporda anlaşılır bir dil kullanulmıştır. & & & & \\
\hline & İmla ve noktalama kurallarına dikkat edilmiştir. & & & & \\
\hline & \begin{tabular}{|l} 
Metin içi kaynakça göstermiștir. \\
\end{tabular} & & & & \\
\hline & $\begin{array}{l}\begin{array}{l}\text { Araştırma dosyasında istenen tüm bōlümler yer } \\
\text { almaktadır. }\end{array} \\
\end{array}$ & & & & \\
\hline \multirow{3}{*}{ 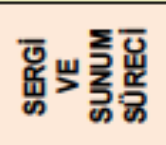 } & Proje, sergi için bir poster sunuma dōnūștürülmüștūr. & & & & \\
\hline & Poster sunumda görsel malzeme kullanılmıştır. & & & & \\
\hline & Poster sunumda yazılı malzeme kullanılmıştır. & & & & \\
\hline \multirow{4}{*}{ 萝 } & \begin{tabular}{|l|lll}
$\begin{array}{l}\text { Proje süresince öğretmenle bilgi alışveriģinde } \\
\text { bulunulmustur. }\end{array}$ \\
\end{tabular} & & & & \\
\hline & Proje gün/üğgü düzenli olarak tutulmuştur. & & & & \\
\hline & Araştırma, çalışma planına uygun gerçekleştirilmiştir. & & & & \\
\hline & Belirienen tarihte rapor teslim edilmiștir. & & & & \\
\hline \multirow{2}{*}{ Degerlenairme } & Toplam & & & & \\
\hline & Not (Yüzlü̈k Sistemde) & & & & \\
\hline
\end{tabular}

